\title{
Tectonic setting of Middle Devonian to Lower Carboniferous rocks in the Magdalen Basin
}

\author{
P. Durling* and F. Marillier \\ Geological Survey of Canada, Atlantic Geoscience Centre, \\ P.O. Box 1006, Dartmouth, Nova Scotia B2Y 4A2, Canada
}

Date Received July 24, 1993

Date Accepted January 5, 1994

\begin{abstract}
Seismic reflection data in the Gulf of St. Lawrence were used to construct an isopach map of the Horton Group (Middle Devonian-Early Carboniferous) in the Magdalen Basin. The map shows that the Horton Group was deposited in basins that developed parallel to the offshore extension of structural trends in New Brunswick and the Gaspe Peninsula. Horton Group strata were deposited in narrow linear fault bounded basins, presently up to $8 \mathrm{~km}$ deep, and in broad sag basins up to $3 \mathrm{~km}$ deep. The sag basins may thin latterally to form sedimentary veneers less than $1 \mathrm{~km}$ thick. The fault bounded basins are mostly half-grabens and they developed during an early crustal extension phase. The largest and deepest basin strikes northeast-southwest, almost parallel to the Moncton Basin in New Brunswick. Sag basins and thin veneers are not fault controlled and are widespread, underlying most of the Magdalen Basin. They probably formed later than the fault bounded basins in response to the onset of a regional subsidence phase.

Deformation of Horton Group rocks in the Magdalen Basin is concentrated in fault zones up to $20 \mathrm{~km}$ wide, and mainly affected deep subbasins, where thrust faults and possible flower structures are observed. An early deformation phase occurred towards the end of Horton Group sedimentation (Late Tournaisian-Early Visean) and a later phase occurred, with less intensity, during the deposition of Visean to ?Namurian sediments. The first phase of deformation affected most of the Magdalen Basin, whereas the second phase affected mainly the southern areas.
\end{abstract}

Des données de sismique réflexion dans le Golfe du Saint-Laurent ont été utilisées pour construire une carte isopaque du Groupe d'Horton (Dévonien moyen - Carbonifère précoce) dans le bassin de la Madeleine. Cette carte montre que le Groupe d'Horton a été déposé dans des bassins développés parallèlement au prolongement en mer de directions structurales du Nouveau Brunswick et de Gaspésie. Les strates du Groupe d'Horton ont été déposées dans des bassins linéaires étroits bordés de failles, ayant maintenant jusqu'à $8 \mathrm{~km}$ de profondeur, et dans de larges bassins d'affaissement ayant jusqu'à $3 \mathrm{~km}$ de profondeur. Les bassins d'affaissement peuvent s'amincir latéralement pour former des plaques sédimentaires de moins d'un kilomètre d'épaisseur. Les bassins bordés de failles sont surtout des demi-grabens qui se sont développés pendant une première phase d'extension. Le plus grand et le plus profond de ces bassins a une direction nord-est - sud-ouest, presque parallèle au bassin de Moncton au Nouveau Brunswick. Les bassins d'affaissement et les plaques sédimentaires ne sont pas contrôlés par des failles et sont répartis presque partout sous le bassin de la Madeleine. Ils se sont probablement formés après les bassins bordés de failles, en réponse à une phase de subsidence régionale.

La déformation des roches du Groupe d'Horton dans le bassin de Madeleine est concentrée dans des zones de failles dont la largeur atteind $20 \mathrm{~km}$, et elle a principalement affecté des sous-bassins profonds où des failles de chevauchement et peut-être des "flower structures" sont observées. La première phase de déformation a eu lieu vers la fin de la sédimentation du Groupe d'Horton (Tournésien Tardif-Viséen précoce), puis une autre, moins intense, a eu lieu pendant le dépôt des sédiments du Viséen au Namurien(?). La première phase de déformation a affecté la majeure partie du bassin de la Madeleine, tandis que la seconde en a principalement affecté les régions méridionales.

[Traduit par la rédaction]

\section{INTRODUCTION}

The Magdalen Basin, one of several basins that make up the composite Maritimes Basin, lies beneath the Gulf of St. Lawrence (Fig. 1). It developed between the Middle Devonian and the Permian immediately following the Acadian Orogeny (Ruitenberg and McCutcheon, 1982; Keppie, 1982). Rocks of the Fountain Lake and Horton groups (Middle Devonian to Early Carboniferous) include some of the oldest sediments deposited in the Magdalen Basin, and analysis of their structural and depo-

\footnotetext{
*Present address: Durling Geophysics, 36 Beaufort Drive, Dartmouth, Nova Scotia, B2W 5 V4
}

sitional setting is the key to understanding the early development of the basin.

Regional studies of the Horton Group in the northern Appalachians (Kelly, 1967; Webb, 1969; Belt, 1968; Howie and Barss, 1975; Bradley, 1982) have been based mainly on onshore field observations and scant offshore data, and give an incomplete view of its stratigraphy and structural setting. Previous seismic studies in the Gulf of St. Lawrence focused on sedimentary infill (e.g., Grant and Moir, 1992), basement features and distribution of main Horton Group subbasins (Durling and Marillier, 1990a). In this paper we present an extension of our previous work in the Magdalen Basin using seismic reflection data to study the Horton Group rocks. We discuss their 


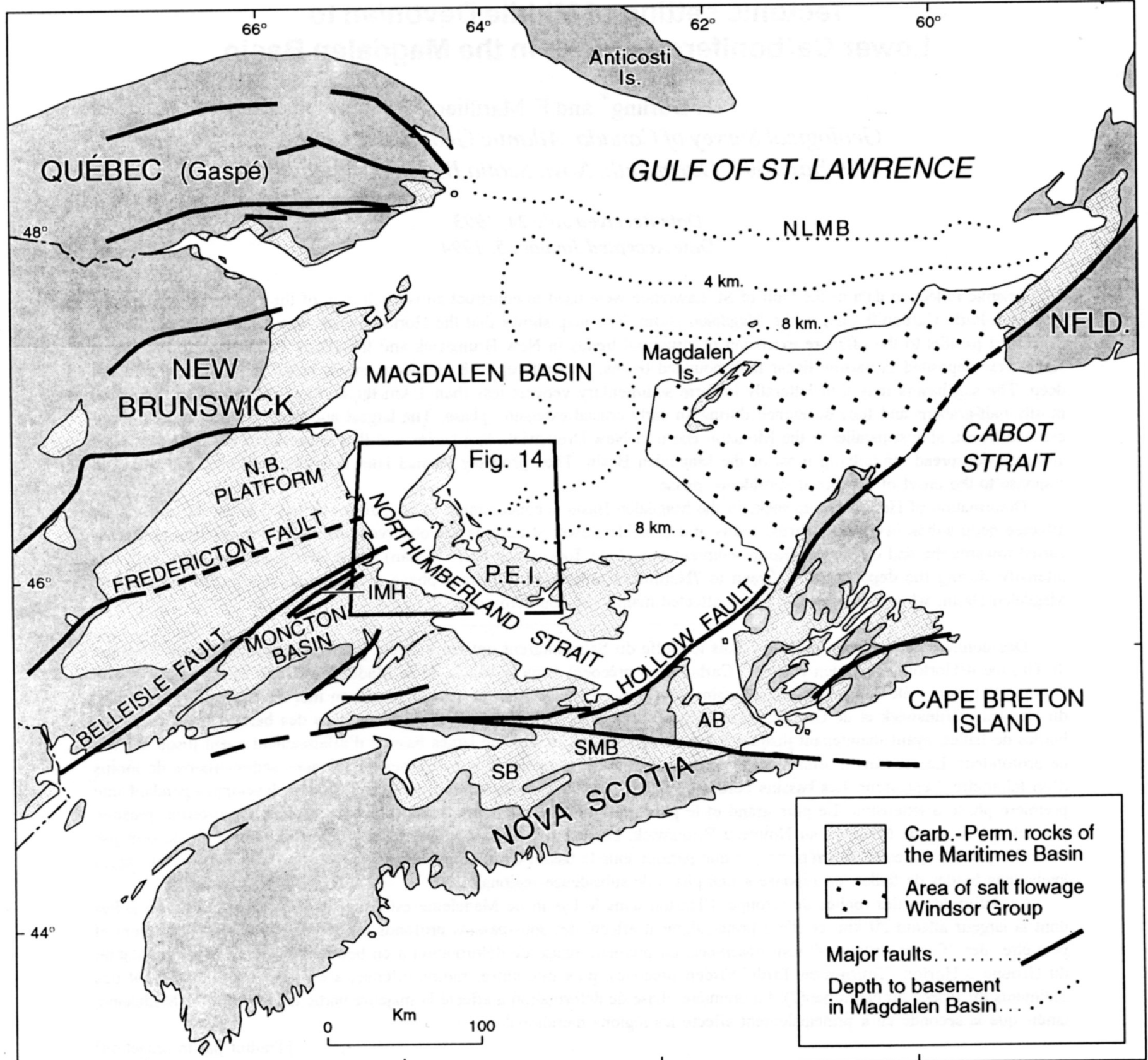

Fig. 1. Location map showing the distribution of Carboniferous to Permian rocks of the Maritimes Basin, a composite basin made up of numerous onshore and offshore basins. The Magdalen Basin, the largest Carboniferous basin, is indicated in the offshore by contours depicting depth to Acadian basement (after Durling and Marillier, 1993). $\mathrm{AB}=$ Antigonish Basin; $\mathrm{IMH}=$ Indian Mountain Horst; NLMB $=$ northern limit of Magdalen Basin; SB = Shubenacadie Basin; SMB = St. Mary's Basin.

tectonic setting during deposition, their distribution, and the type and timing of deformation of Horton Group subbasins. Our Horton Group isopach map, derived mainly from seismic reflection data, should facilitate onshore/offshore correlations by providing a regional overview of the distribution of Horton Group rocks in the Gulf of St. Lawrence.

\section{STRATIGRAPHY}

The earliest record of deposition (Fig. 2) in the Maritimes Basin is represented by the Fountain Lake Group and its equiva- lents (i.e., Fisset Brook, McAras Brook, and McAdam Lake formations; bimodal basalt-rhyolite suites and interbedded redbeds; Dostal et al., 1983; Blanchard et al., 1984), and the Horton Group (red and grey alluvial fan, lacustrine and fluvial deposits; Knight, 1983; Carter and Pickerill, 1985; Hamblin and Rust, 1989). These rocks were emplaced or deposited immediately following the Acadian Orogeny and range in age from Middle Devonian to Early Visean. Sediments were locally derived and were deposited in fault bounded troughs that were separated by basement horsts and upland areas (Howie and Barss, 1975; Kelly, 1967). Younger strata progressively over- 


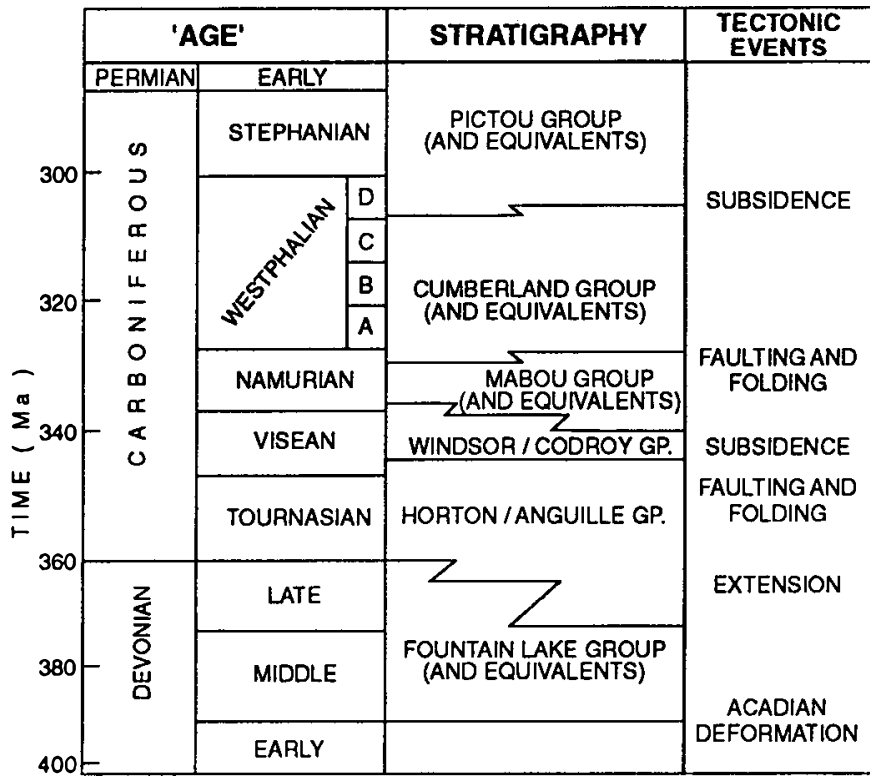

Fig. 2. Stratigraphy of Upper Paleozoic rocks and timing of main tectonic events in the Maritimes Basin (modified after Ryan et al., 1991; Ruitenberg and McCutcheon, 1982)

stepped the basin margins and onlapped onto basement, thereby increasing the size of the basin through time.

The Horton Group commonly comprises coarse-grained clastics at the bottom and top with fine-grained sediments in the middle and is generally subdivided into two to three formations on the basis of lithology (Williams et al., 1985). At a few localities, an unconformity occurs within the Horton Group. In the Moncton Basin, an upper redbed package, the Moncton Formation, is subdivided into a lower Weldon Member and an upper Hillsborough Member (Carter and Pickerill, 1985). The Hillsborough Member is concordantly overlain by the Windsor Group and locally unconformably overlies the Weldon Member. Although some authors assign the Hillsborough Member to the Windsor Group (St. Peter, 1992), we include it in the Horton Group (McCutcheon, 1981; Carter and Pickerill, 1985). In the Antigonish Basin, the Wilkie Brook Formation (Horton Group) is unconformably underlain by the Upper Devonian Horton Group (Martel et al., 1993) and concordantly overlain by the Windsor Group. The Coldstream Formation in the Shubenacadie Basin is an age equivalent of the Wilkie Brook Formation and may occupy a similar stratigraphic position (Utting et al., 1989). Murphy et al. (1993) identified a contact that may locally represent an intra-Horton Group angular unconformity within the St. Mary's Basin.

Overlying the Horton Group are the mainly marine strata of the Visean Windsor Group. The Windsor Group comprises a thick salt bearing lower evaporite package, locally diapiric, underlying a sequence of interbedded evaporites, limestones and clastics (Giles, 1981). The Windsor Group is overlain by the Mabou (Namurian), Cumberland (Westphalian) and Pictou groups (Westphalian to Permian). Deposition of the Upper Carboniferous rocks was accompanied by intermittent fault movements causing local unconformities while continuous sedimentation occurred elsewhere (Kelly, 1967).

Carboniferous deformation in Atlantic Canada has been largely attributed to the Maritime Disturbance (Poole, 1967). This event periodically produced open folds and faults in the Lower Carboniferous rocks. Two distinct phases of deformation are recognized in southern New Brunswick (Fig. 2): a pre-Windsor Group (pre-Visean) compressional episode resulting in folding, faulting and basin inversion (Ruitenberg and McCutcheon, 1982; Nickerson, 1991; St. Peter, 1992), and a second phase involving pre-Lower Westphalian rocks where a fracture cleavage (Ruitenberg and McCutcheon, 1982), strike-slip faults and westward directed thrusts (Nance, 1987) developed along the southern coast of New Brunswick. Other manifestations of the Maritime Disturbance are documented in Nova Scotia (Keppie, 1982) and in Newfoundland (Knight, 1983).

\section{Seismic database}

Seismic reflection data were acquired between 1967 and 1986 by the petroleum industry and as part of the Lithoprobe Program (Marillier et al., 1989) in the Gulf of St. Lawrence (Fig. 3). We interpreted over $30,000 \mathrm{~km}$ of data for this study, but only those seismic lines that contributed data to the Horton Group isopach map are displayed in Figure 3. The data vary widely in quality, largely as a function of geology, acquisition parameters and processing techniques, but not necessarily as a function of age. Well control for this study was provided by eight exploratory wells (Fig. 3; Table 1).

\section{SEISMIC STRATIGRAPHY}

\section{Basement}

Basement to the Magdalen Basin comprises Precambrian to Devonian rocks that were deformed during the Acadian Orogeny. These rocks were drilled in two wells (Northumberland Strait F-25 and Porthill No. 1; Table 1, Fig. 4a, b). The seismic character of the basement rocks varies widely from chaotic to dipping discontinuous reflections. Along the northern edge of the Magdalen Basin, Carboniferous rocks lie with angular unconformity on the Lower Paleozoic rocks of the Anticosti Basin. The unconformity produces a high amplitude, continuous reflection.

Overlying the Acadian metamorphic basement rocks are the Fountain Lake and Horton groups. The McAras Brook Formation (Fountain Lake Group equivalent; Dostal et al., 1983) was drilled in the Northumberland Strait F-25 well (Pe-Piper and Jansa, 1986; Table 1, Fig. 4a). At this location, however, the McAras Brook Formation is too thin to be identified on seismic sections. For this, and other reasons discussed below, we did not attempt to distinguish the Fountain Lake Group from the Horton Group in this study.

\section{Horton Group}

The Horton Group was identified in seven wells in the Gulf of St. Lawrence and onshore Prince Edward Island (Table 1). Seismic profiles adjacent to these wells were studied to establish the seismic character of the Horton Group.

At the Northumberland Strait F-25 well (Fig. 4a), the 


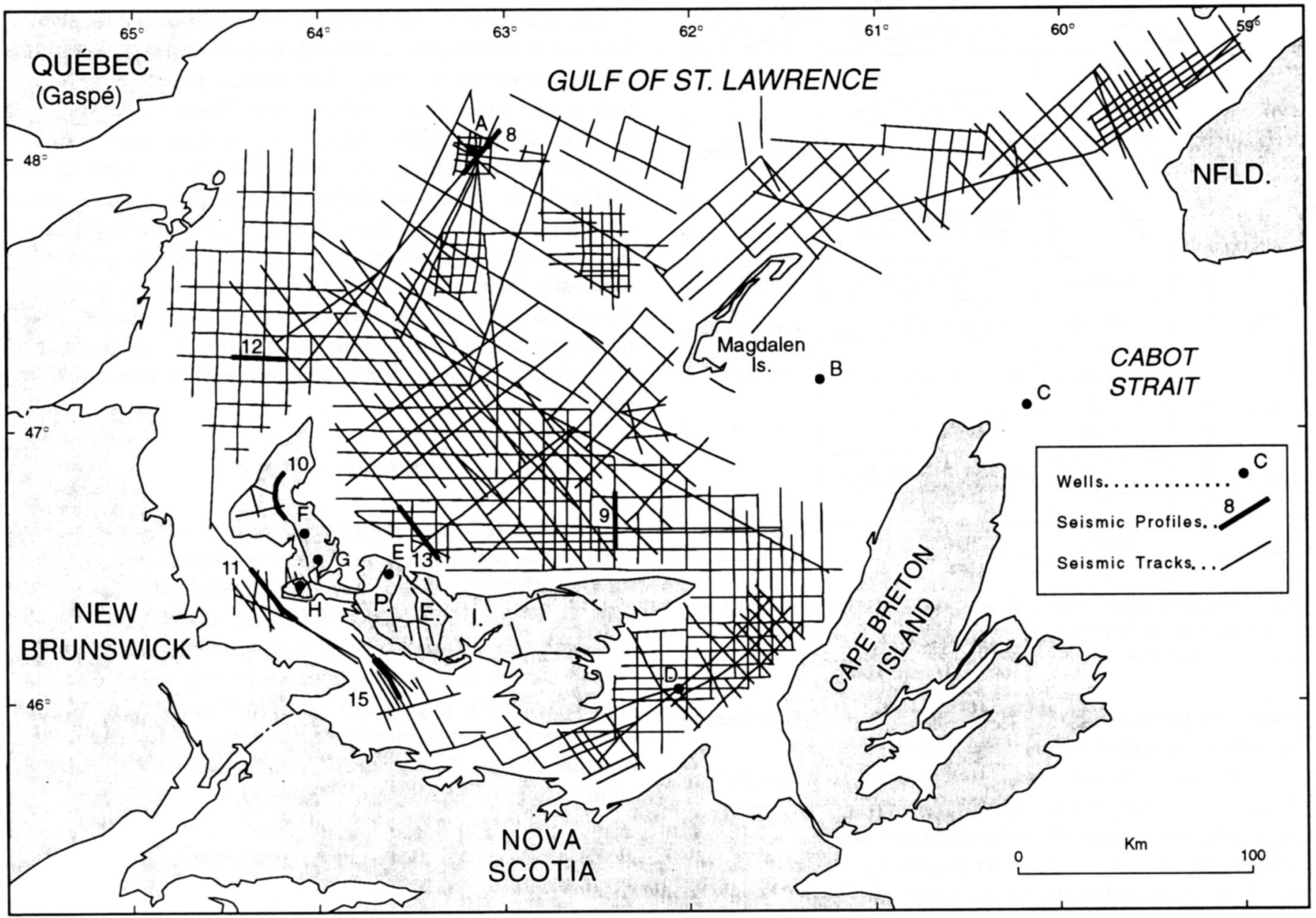

Fig. 3. Location of the seismic reflection profiles used to derive the Horton Group isopach map (Fig. 6). Seismic sections displayed in this paper are highlighted and labelled with their corresponding figure number. Wells are: (A) Bradelle L-49, (B) Cap Rouge F-52, (C) St. Paul P-91, (D) Northumberland Strait F-25, (E) Irishtown No. 1, (F) Porthill No.1, (G) McDougall No. 1, and (H) Wellington Station No. 1.

Table 1. Stratigraphic tops identified in wells that penetrated the Horton Group or older rocks in the Magdalen Basin.

\begin{tabular}{|c|c|c|c|c|c|}
\hline Well Name & Top Windsor & Top Horton & Top F.L. & Top Basement & Total Depth \\
\hline Bradelle L-49 & $2885 \mathrm{~m}(1.54 \mathrm{~s})$ & $2920 \mathrm{~m}(1.56 \mathrm{~s})$ & $\mathrm{n} / \mathrm{a}$ & $\mathrm{n} / \mathrm{a}$ & $4421 \mathrm{~m}(2.13 \mathrm{~s})$ \\
\hline Cap Rouge F-52 & spudded & $4816 \mathrm{~m}(1.98 \mathrm{~s})$ & $5041 \mathrm{~m}(2.22 \mathrm{~s})$ & $\mathrm{n} / \mathrm{a}$ & $5059 \mathrm{~m}(2.17 \mathrm{~s})$ \\
\hline Irishtown No. 1 & $1915 \mathrm{~m}(0.95 \mathrm{~s})$ & $3027 \mathrm{~m}(1.44 \mathrm{~s})$ & $\mathrm{n} / \mathrm{a}$ & $\mathrm{n} / \mathrm{a}$ & $4108 \mathrm{~m}(1.94 \mathrm{~s})$ \\
\hline McDougall No. 1 & $\mathrm{n} / \mathrm{a}$ & $1134 \mathrm{~m}(0.64 \mathrm{~s})^{*}$ & $\mathrm{n} / \mathrm{a}$ & $\mathrm{n} / \mathrm{a}$ & $2768 \mathrm{~m}(1.35 \mathrm{~s})^{*}$ \\
\hline \multicolumn{6}{|l|}{ Northumberland } \\
\hline Strait F-25 & Spud & $2015 \mathrm{~m}(0.98 \mathrm{~s})$ & $2514 \mathrm{~m}(1.23 \mathrm{~s})$ & $2786 \mathrm{~m}(1.33 \mathrm{~s})$ & $3001 \mathrm{~m}(1.41 \mathrm{~s})$ \\
\hline Porthill No. 1 & $\mathrm{n} / \mathrm{a}$ & $\mathrm{n} / \mathrm{a}$ & $\mathrm{n} / \mathrm{a}$ & $1408 \mathrm{~m}(0.81 \mathrm{~s})^{*}$ & $1417 \mathrm{~m}(0.81 \mathrm{~s})^{*}$ \\
\hline St. Paul P-91 & $2098 \mathrm{~m}(1.03 \mathrm{~s})$ & $2584 \mathrm{~m}(1.21 \mathrm{~s})$ & $\mathrm{n} / \mathrm{a}$ & $\mathrm{n} / \mathrm{a}$ & $2885 \mathrm{~m}(1.31 \mathrm{~s})$ \\
\hline \multicolumn{6}{|l|}{ Wellington } \\
\hline Station No. 1 & $1262 \mathrm{~m}(0.71 \mathrm{~s})$ & $1768 \mathrm{~m}(0.91 \mathrm{~s})$ & $\mathrm{n} / \mathrm{a}$ & $\mathrm{n} / \mathrm{a}$ & $2961 \mathrm{~m}(1.43 \mathrm{~s})^{*}$ \\
\hline
\end{tabular}

The stratigraphic tops are from the respective well history reports, except for the Northumberland Strait well, which are taken from Pe-Piper and Jansa (1986). Depths are given in metres below rotary table and time is in seconds (two-way travel time). Add 0.08 seconds to all travel times listed for the Northumberland Strait well to account for the down dip projection of the well onto Figure 4a. Asterisks denote extrapolated travel times based on a check-shot survey from the Wellington Station well. F.L. = Fountain Lake Group. For well locations see Figures 3 and 14. 

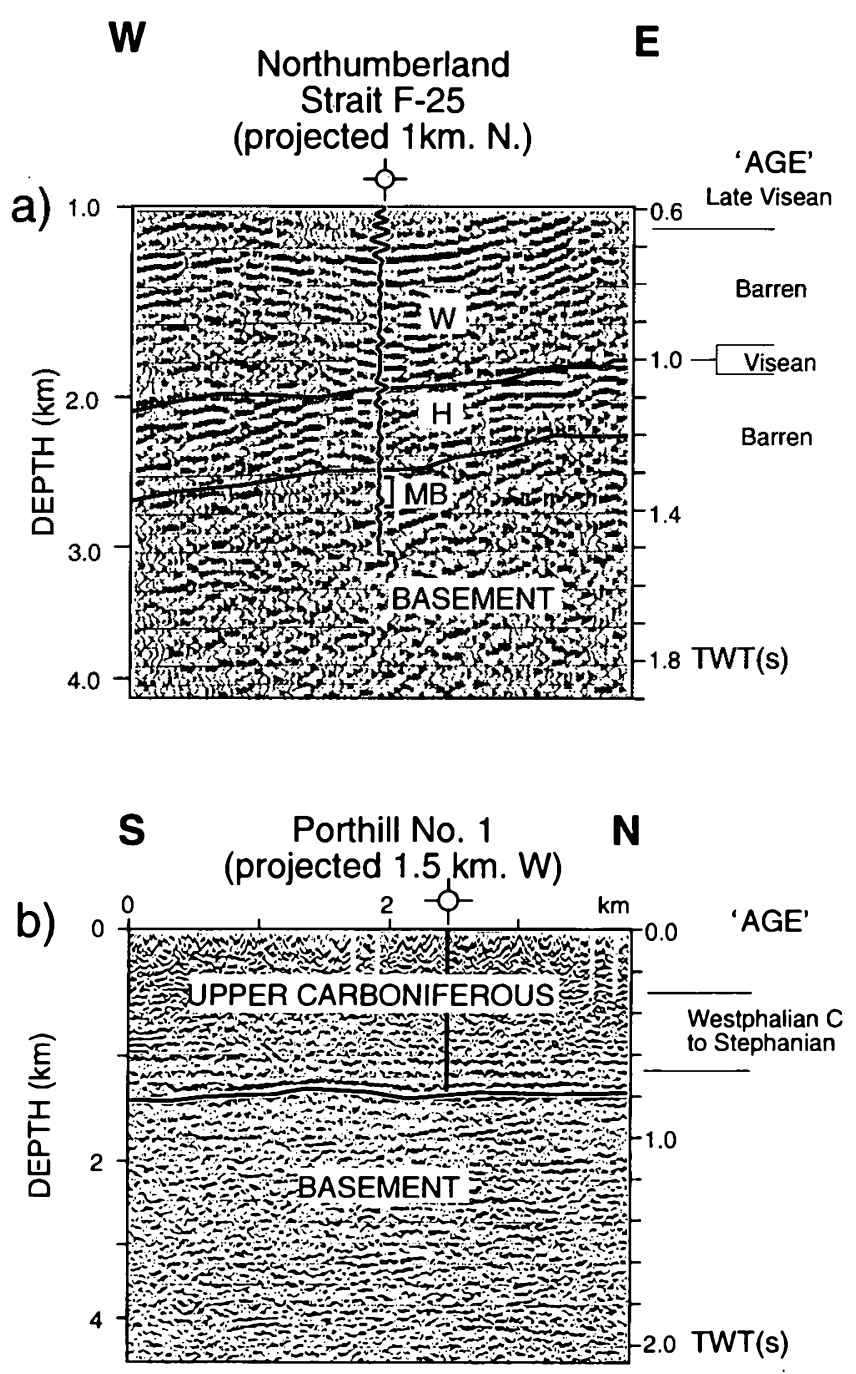

Fig. 4. Seismic sections in the vicinity of (a) the Northumberland Strait F-25 well and (b) the Porthill No. 1 well. The synthetic seismogram used to correlate the F-25 well with the seismic data is shown in (a). A check-shot survey from the Wellington Station No. 1 well was used for correlation in (b). Biostratigraphic age data is shown for the F-25 well (Barss et al., 1979) and the Porthill well (Barss et al., 1963). $\mathrm{W}=$ Windsor Group; $\mathrm{H}=$ Horton Group; $\mathrm{MB}=$ McAras Brook Formation volcanics.

Horton Group is represented by continuous to discontinuous reflections with frequencies of the seismic signal comparable to those of the Windsor Group. Strata of the Horton Group are interpreted to be flat lying and generally undeformed. The sediment-basement contact in this area is interpreted where an abrupt change occurs in seismic reflection character from discontinuous to chaotic reflections.

In the Bradelle L-49 well (Fig. 5a) about $1500 \mathrm{~m}$ of Horton Group strata were drilled. They are represented by medium amplitude, discontinuous reflections. This seismic character contrasts with the more continuous parallel reflections of the Windsor Group and younger rocks that unconformably overlie the Horton Group, and with basement below (see also Fig. 8). The Horton Group/basement interface does not correspond to a distinct reflection, rather it is interpreted where the seismic reflection character changes. This change was commonly the ba- sis for identifying the Horton Group/basement interface throughout the Magdalen Basin.

The Horton Group in the Irishtown No. 1 (Fig. 5b) and Wellington Station No. 1 wells (Fig. 5c) is overlain by a sequence of basic volcanics with some interbedded redbeds. The volcanics occur locally and are recognized only in the vicinity of these wells. Medium to low amplitude, discontinuous reflections characterize the Horton Group in this area. The high amplitudes from the overlying volcanics permit identification of a Horton Group top, but the bottom of the sequence cannot be identified accurately because the seismic character of the Horton Group gradually fades away to background seismic noise towards the bottom of the section. This phenomenon occurs in the deeper parts of the Magdalen Basin and is likely due to the induration of the Horton Group rocks at depth

Seismic profiles adjacent to the McDougall No. 1 well show a chaotic seismic character for the Horton Group (Fig. 5d). This character is different from other Horton Group sections and, if not for the well, it is doubtful that these reflections would have been identified as Horton Group. Bedding attitudes measured from drill core are highly variable and range from $12^{\circ}$ to verti$\mathrm{cal}$ in the well. This may account for the lack of seismic reflections. For comparison, the dip of Horton Group beds in the Wellington well ranges from $5^{\circ}$ to $20^{\circ}$ with a single $? 30^{\circ}$ measurement.

The subdivisions of the Horton Group are generally elusive in the seismic data with the possible exception of an intra-Horton Group unconformity. In Figure 5a, a thin ( $30 \mathrm{~m})$ non-marine clastic unit lies unconformably on Tournasian age rocks and is concordantly overlain by Visean marine limestones (Shell et al., 1974). Away from the Bradelle well, this unit is conformable with strata above and below it. Soquip (1987) correlated this unit with the Hillsborough Member in the Moncton Basin (Carter and Pickerill, 1985).

The top of the Horton Group was generally identified by recognizing the high amplitude basal reflections of the immediately overlying Windsor Group (Giles and Durling, 1993). These basal reflections are laterally continuous for up to 100 $\mathrm{km}$ or more, and can be tied with confidence from one well to another. This horizon is much easier to pick than top of basement, which has a highly variable seismic character. The seismic signature of Horton Group rocks is relatively uniform, although it becomes less organized in faulted areas.

\section{HoRTON GROUP ISOPACH MAP}

The isopach map in the Gulf of St. Lawrence (Fig. 6) was derived by calculating the thickness of sediments between Acadian basement and the base of the Windsor Group, previously mapped by Durling and Marillier (1993). This stratigraphic interval includes Horton Group rocks as well as Fountain Lake Group and equivalent rocks. However, we believe that except for a few places, the bulk of the measured thicknesses represents Horton Group rocks.

The map was created by digitizing the seismic horizons, interpolating to achieve a $1 \mathrm{~km}$ data spacing along track, converting the two-way travel time data to depth, calculating the thickness between the two horizons, and then subjecting the 

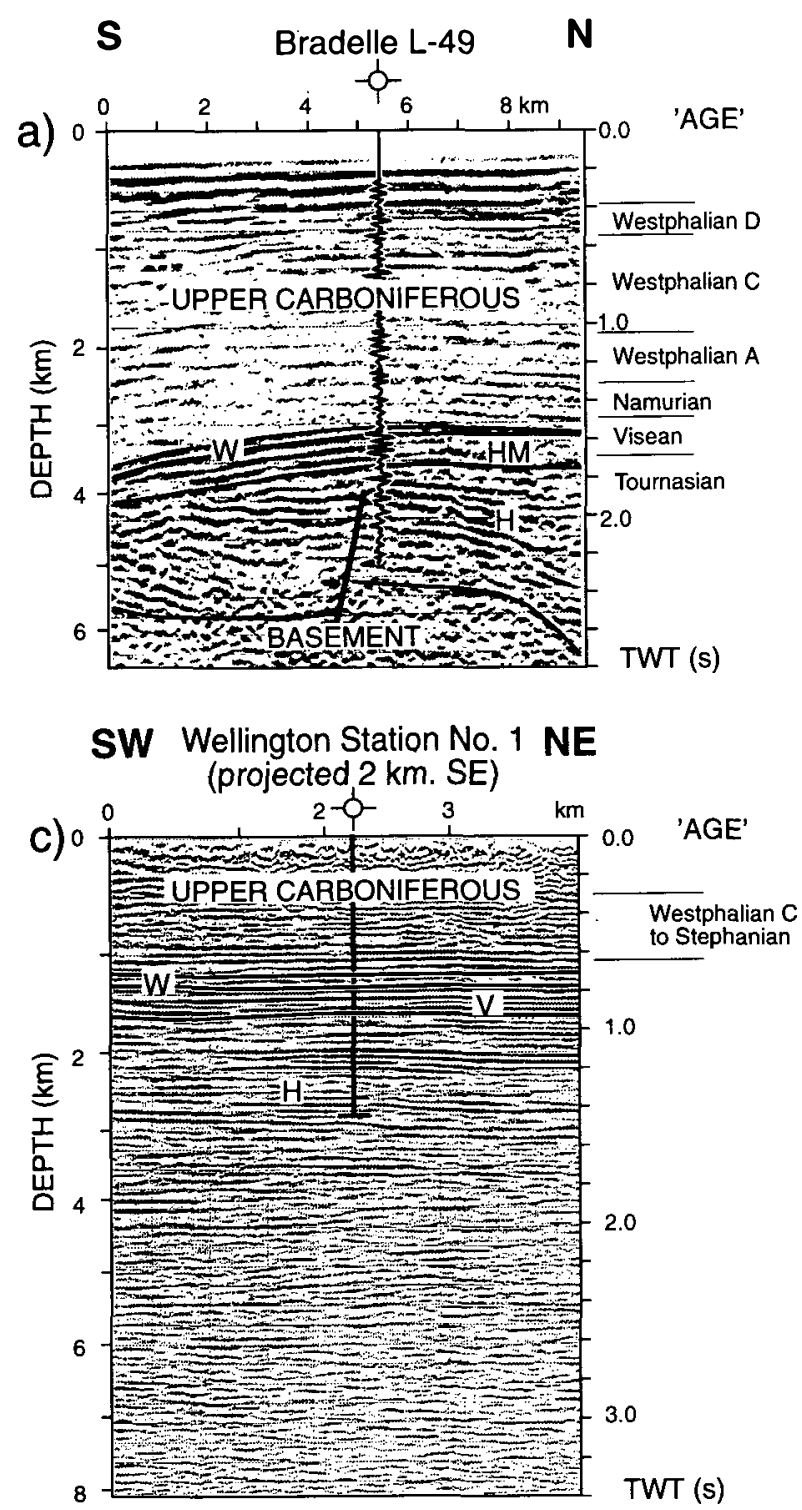
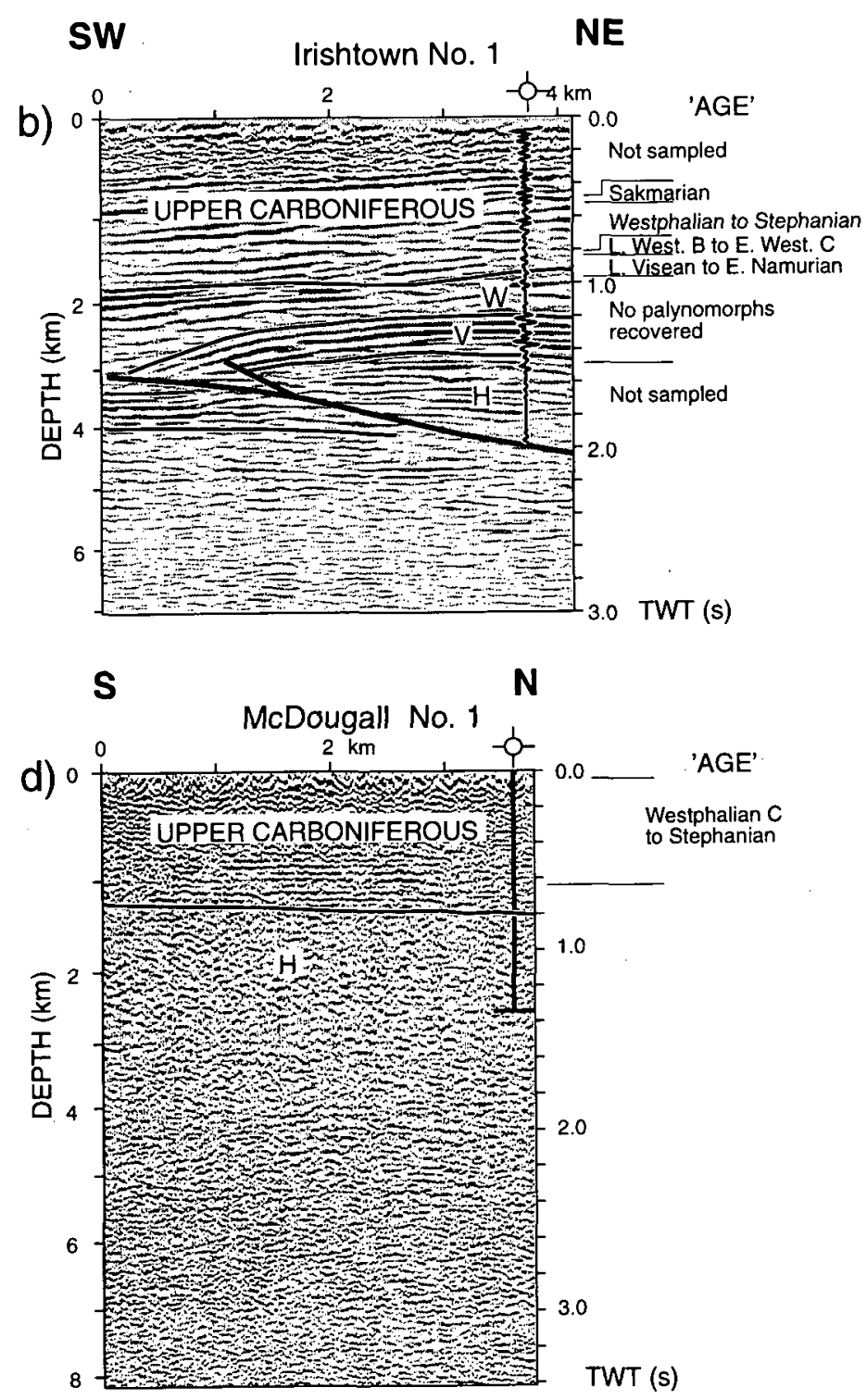

Fig. 5. Seismic sections tying with or in the vicinity of wells used to identify the seismic character of the stratigraphic units discussed in the text: (a) Bradelle L-49; (b) Irishtown No. 1; (c) Wellington Station No. 1; (d) McDougall No. 1. Synthetic seismograms used for correlating the well and seismic data are shown in (a) and (b). For (c) and (d), correlation was accomplished using a check-shot survey from the Wellington Station No. 1 well. Biostratigraphy is after (a) Shell et al. (1974), (b) Barss et al. (1979) and (c) and (d) Barss et al. (1963). V = Hillsborough volcanics; $\mathrm{HM}=$ Hillsborough Member; other labels same as in Figure 4.

interpolated data to gridding and contouring routines. Depths were calculated using an average velocity function (Fig. 7) computed from 43 seismic refraction profiles distributed over the entire basin (Hobson and Overton, 1973). We used refraction rather than stacking velocities because the latter have a much larger scatter, and because refraction velocities are closer to the velocities derived from sonic logs in the Magdalen Basin. The gridding program we used does not handle faults properly and represents them as steep surfaces rather than offsets in the gridded surface. We manually modified the contours adjacent to major faults so that the gridded map more accurately represents the seismic data.

In onshore regions, isopach data were compiled from seismic studies in the Sackville (Martel, 1987) and Moncton (Howie and Cumming, 1963) basins and from measured thicknesses on outcrops in Cape Breton Island (Hamblin, 1989). Thickness data measured from outcrops represent estimates of the original depositional thickness of the Horton Group, whereas thickness data calculated from seismic reflection data represent present day structural thicknesses of the Horton and the Fountain Lake groups.

Several types of errors may affect the isopach values. The largest source of error is likely due to the difficulty in identifying top of basement. In most areas, however, the basement pick is constrained by dense data coverage and by ties between seismic profiles. In case of doubt, the shallowest possible value was picked, and for this reason, we feel that this type of error, if present, results in an underestimation of the isopach values.

Another type of error may arise from the inclusion of Windsor age clastics in the Horton Group. Geological field observations indicate that such errors have occurred onshore (Kelly, 1967). However, because the base Windsor Group in the 


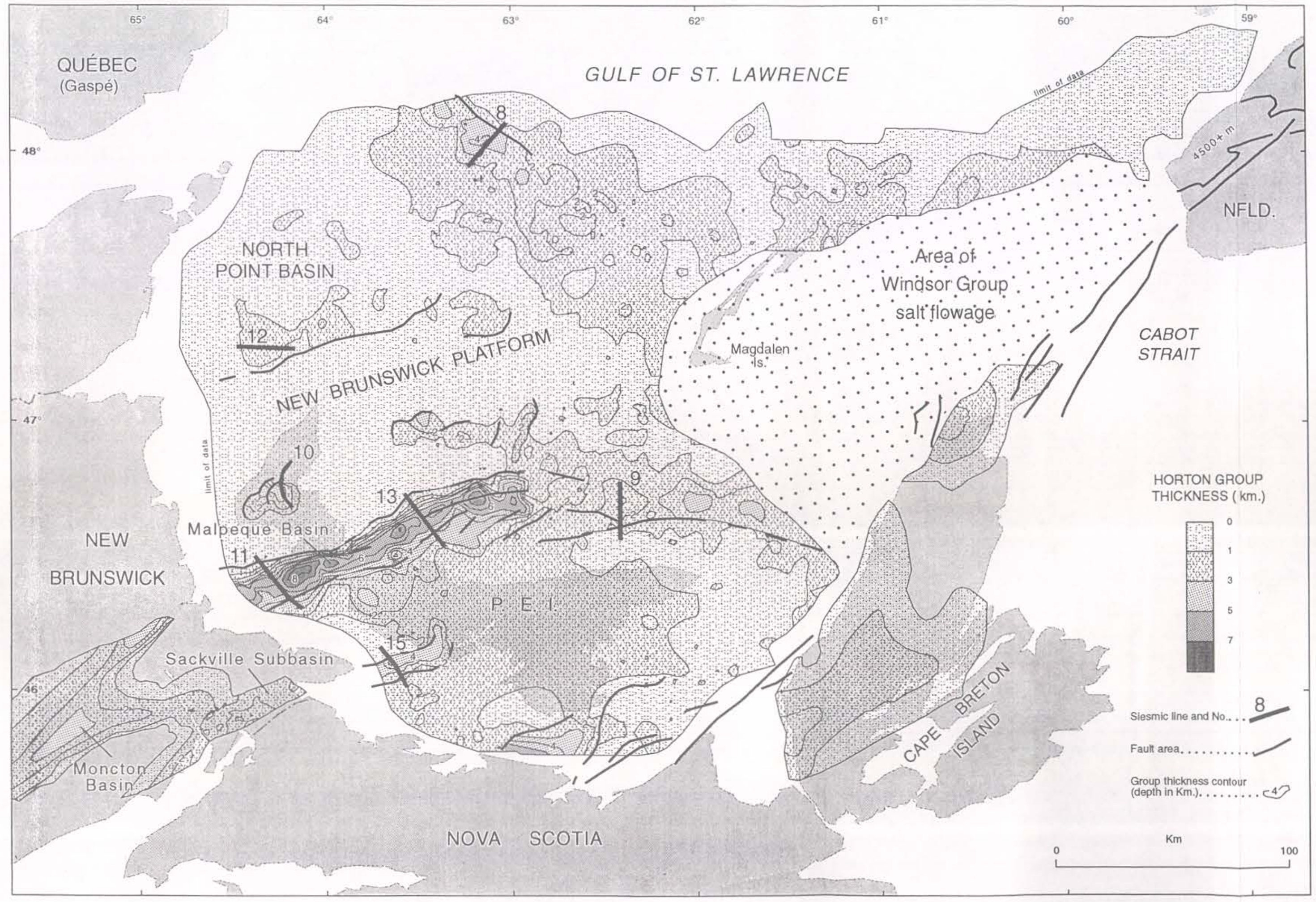

Fig. 6. Isopach map of the Horton Group rocks in the Magdalen Basin and adjacent areas. Contour interval is $1 \mathrm{~km}$. Even valued contours are

labelled and the pattern changes at odd valued contours. Onshore data are compiled from measured outcrops and seismic surveys (see text). 


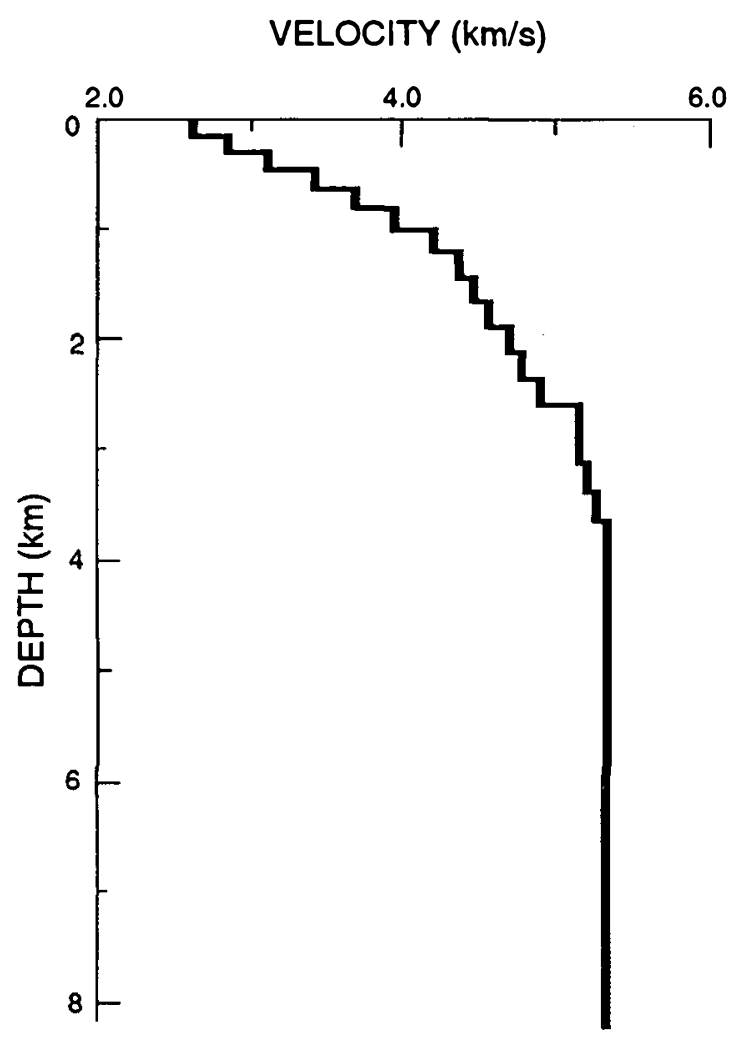

Fig. 7. Velocity model used to convert two-way reflection times to depths. It is an average of $\mathbf{4 2}$ models derived from seismic refraction profiles in the Magdalen Basin (Hobson and Overton, 1973). The model was made by calculating the average velocity in layers of constant time thickness $(0.1 \mathrm{~s})$.

Magdalen Basin usually corresponds to a well identifiable seismic reflection, we feel that this type of error is not likely. The only exception is the offshore extension of the New Brunswick Platform where the base Windsor Group cannot be identified with certainty. This type of error would cause the isopach values to be overestimated.

Errors in the map may also arise from the fact that we did not differentiate Horton Group from Fountain Lake Group rocks. The Fisset Brook Formation in Cape Breton Island (equivalent of the Fountain Lake Group) is generally less than $500 \mathrm{~m}$ thick (Blanchard et al., 1984). In the Cobequid Highlands, the Fountain Lake Group is locally up to $5000 \mathrm{~m}$ thick (Boehner et al., 1986), and thick accumulations of Fountain Lake Group rocks are suspected in the basin immediately offshore from the eastern end of the Cobequid Highlands. Elsewhere, we consider its thickness to be insignificant (see, e.g., the McAras Brook Formation in Fig. 4a). Errors of this type would result in overestimated isopach values of the Horton Group.

In a few small areas void of data the isopach values were interpolated by the gridding program. These areas are the result of either a very wide line spacing (e.g., northwest and west of the Bradelle well area and along the Prince Edward Island coast) or the seismic record length being too short to identify basement confidently (e.g., eastern Prince Edward Island where the Horton Group is probably thicker than shown). The seismic coverage map (Fig. 3) is a guide to the reliability of the isopach map. No isopach data could be obtained in the large triangular area of deformation associated with Windsor Group salt flowage (Fig. 6), and it is too large to be filled with interpolated data.

Rocks of uncertain affinity underlie the area of Windsor Group salt flowage (Durling and Marillier, 1993), but Horton Group rocks are probably present. Spurious noise generated near the numerous salt structures in this area mask the stratigraphy beneath the Windsor Group salt. Horton Group rocks are present in the St. Paul P-91 well (Table 1). They may be traced on seismic reflection profiles on the eastern flank of the Magdalen Basin, between Cape Breton and Newfoundland. Horton Group rocks from this area were not included in this paper because of their complex setting; more work is required in this area to produce an isopach map.

Gravity data cannot be used to control the isopach values because Horton Group rocks have densities similar to that of basement (Marillier and Verhoef, 1989). Moreover, the gravity field in many areas of the Magdalen Basin is dominated by short wavelength anomalies that are usually caused by thick accumulations of Windsor Group salt which has a strong density contrast with surrounding rocks. In these areas, more subtle gravity anomalies are difficult to detect.

Although the thickest accumulations of Horton Group rocks occur locally in the Gulf, the offshore and onshore isopach values are regionally of the same order of magnitude. Generally, the strata are up to $2000 \mathrm{~m}$ thick and they locally thicken to $4000 \mathrm{~m}$ both onshore and offshore. The exception is the very thick basin located along the southeast margin of the offshore extension of the New Brunswick platform. We informally named the basin the Malpeque Basin (Fig. 6). Thickness estimates in the eastern Moncton Basin by Gussow (1953) indicate that thrust repetitions of the Horton Group are preserved in a basin up to $6000 \mathrm{~m}$ thick. Similar thrust relationships can be inferred in the Malpeque Basin where the Horton Group is locally more than $8 \mathrm{~km}$ thick, but generally 5 to $7 \mathrm{~km}$ thick.

\section{Formation of Horton Group basins}

We interpret the Horton Group in the southern Gulf of St. Lawrence to be deposited in two depositional settings: (1) fault bounded basins, and (2) thin veneers and sag basins.

\section{Fault bounded basins}

In the northern Magdalen Basin, a northwest-southeast oriented basin is bounded to the northeast by a steep fault and is characterized by subtle fanning of the strata towards the basin bounding fault (Fig. 8a, b). This subbasin is up to $4 \mathrm{~km}$ deep, at least $50 \mathrm{~km}$ long and $20 \mathrm{~km}$ wide. The discontinuity of the reflections within the basin suggest minor faulting and post-Horton Group deformation which have modified the origina! configuration of the basin. We have attempted to restore its original geometry by flattening an appropriate horizon which post-dates basin deformation. The deeper reflections are restored by moving them vertically by the same amount used to flatten the reference horizon (Fig. 8b). Obviously, this method does not compensate for horizontal deformation. A half-graben geometry is indicated in the restored seismic section. 


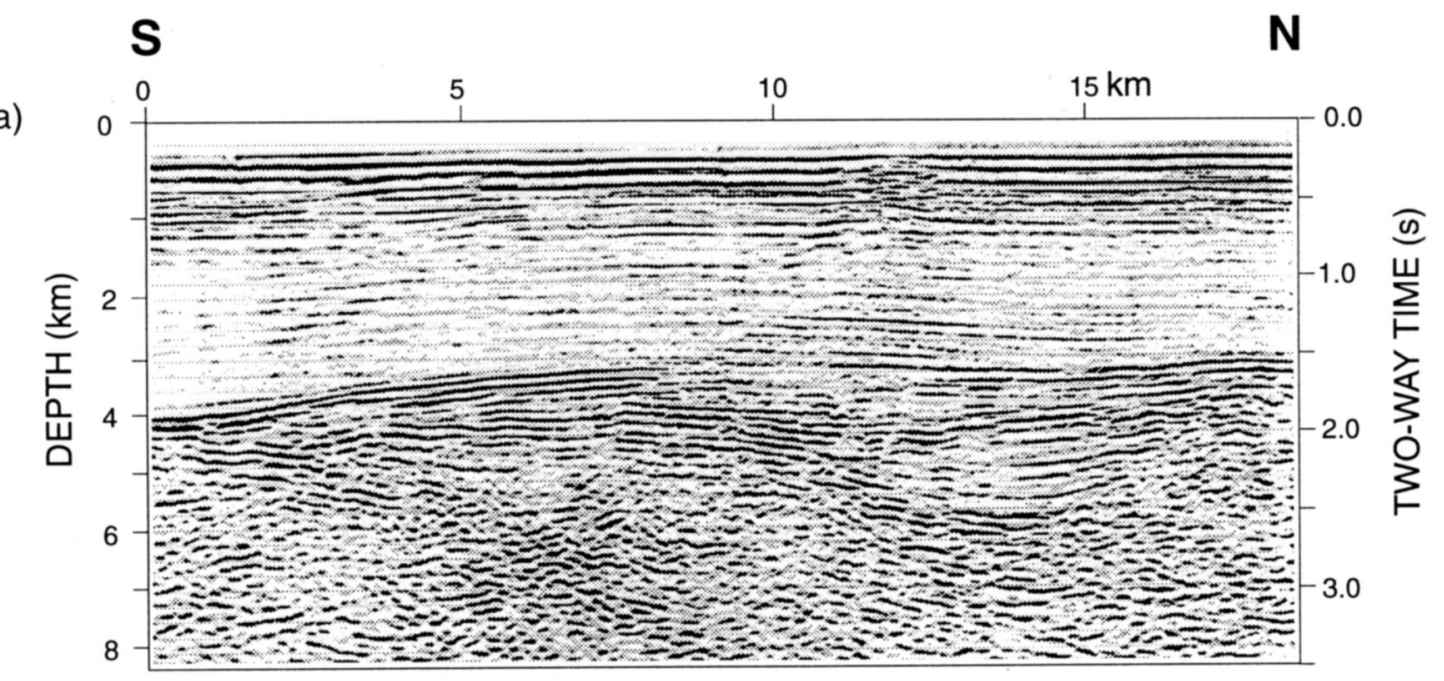

b)

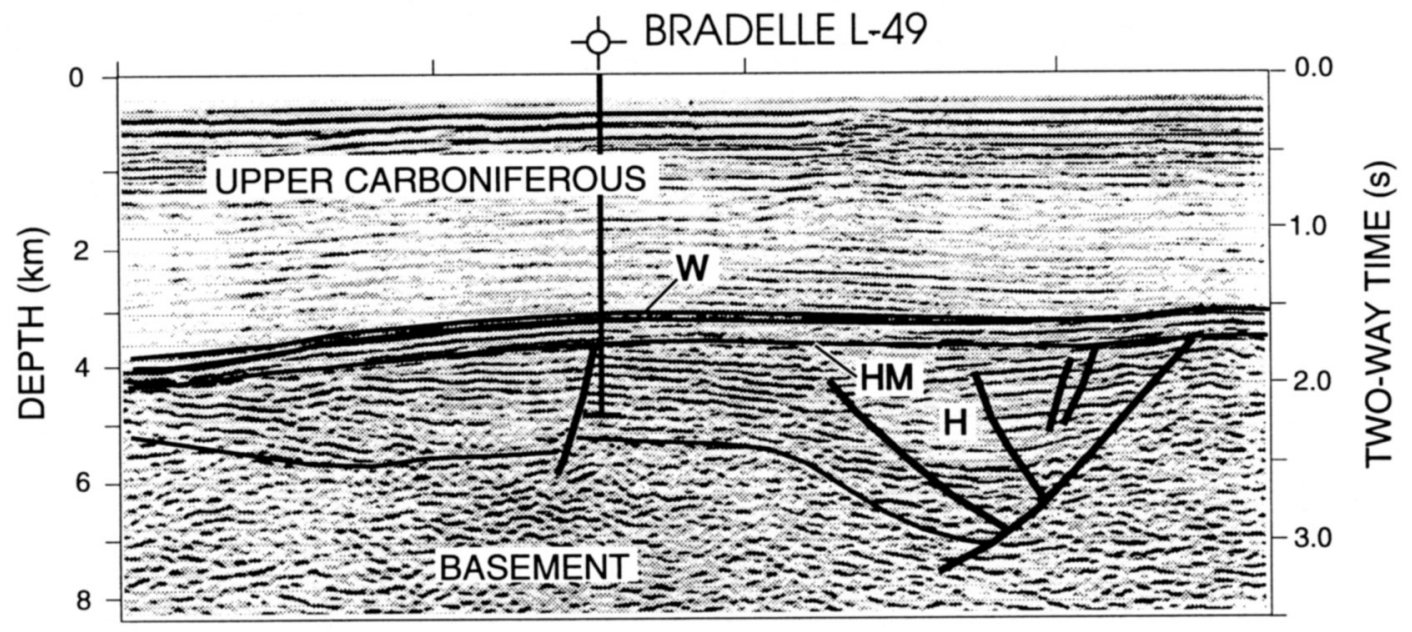

c)

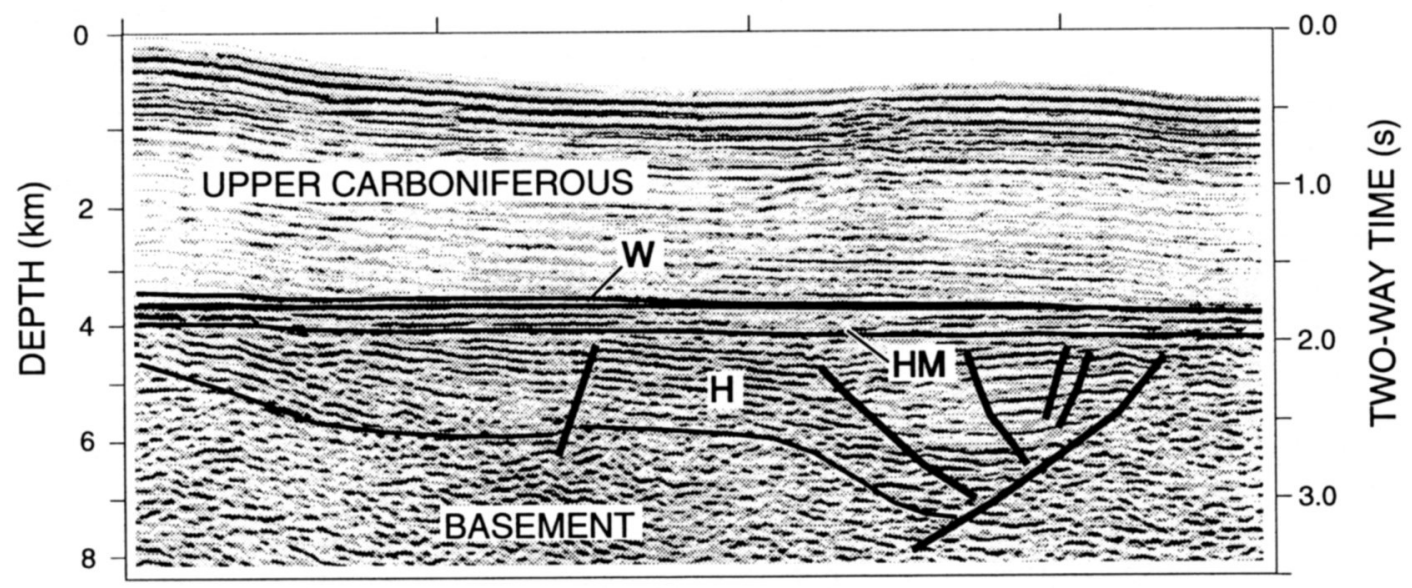

Fig. 8. (a) Uninterpreted seismic section (86-2) tying with the Bradelle L-49 well; (b) interpreted seismic section; and (c) the geometry of Horton Group half-graben has been restored by vertically shifting the reflections so as to flatten the unconformity just below the base of the Windsor Group. Labels same as in Figure 4. For location see Figures 3 or 6.

An east-west oriented basin northeast of Prince Edward Island is bounded to the south by a fault parallel to the coast of the island. Reflections from within the basin can be divided into three seismic units (Fig. 9): lower and upper reflective packages with a seismically quiet package in the middle. Thickening of strata into the bounding fault is indicated, suggesting that this basin developed as a half-graben. The isopach map indicates that the basin is $3 \mathrm{~km}$ deep, however, many of the seismic profiles that cross it reach only to 4.0 seconds TWT, and they do not image the sediment basement interface. Thicknesses in this area should be regarded as minimum estimates. This basin extends to the east beneath the area of evaporite flowage.

Figure 10 displays a seismic reflection profile across a basin we have interpreted as another half-graben. The sediments within this basin are interpreted as Horton Group rocks on the 

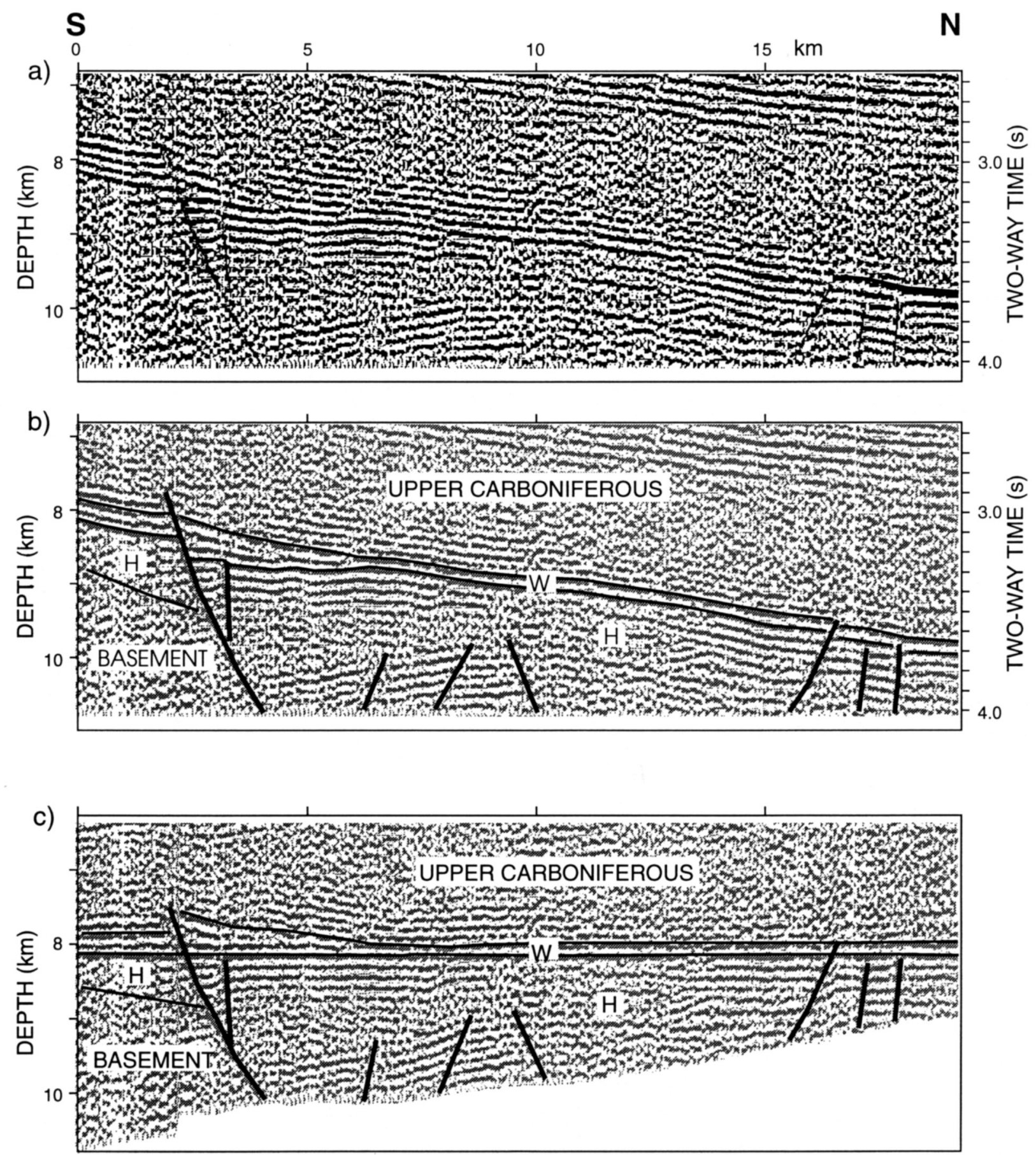

Fig. 9. Seismic section (HAA-015) northeast of Prince Edward Island (a) uninterpreted section (b) interpreted section, and (c) restored by flattening the base Windsor Group horizon. For location see Figures 3 or 6.

basis of seismic character and their stratigraphic position below the Windsor Group. Fanning of strata toward the basin bounding fault is indicated by the seismic data, and the basin geometry is reminiscent of a half-graben. Other small basins are located on the southeastern edge of the New Brunswick platform and in eastern Northumberland Strait. These basins all show reflections indicating varying degrees of fanning strata towards their respective basin bounding faults.

The Malpeque Basin (Fig. 11) is more than $120 \mathrm{~km}$ long, and it is the deepest basin identified in this study. It is bounded to the northwest by a steep fault, and the basin shallows to the southeast. Fanning internal reflections suggest that it may have developed as a half-graben. However, its present geometry reflects post depositional deformation that produced complex structural relationships (see next section), which makes it difficult to determine the original basin configuration. The Malpeque Basin is almost parallel to the Moncton Basin in New Brunswick and it may be its offshore extension.

\section{Thin veneers and sag basins}

Our distinction between a sag basin and a veneer is somewhat arbitrary. Thin veneers range in thickness from less than $100 \mathrm{~m}$ to about $1000 \mathrm{~m}$ and extend over large areas. They are 


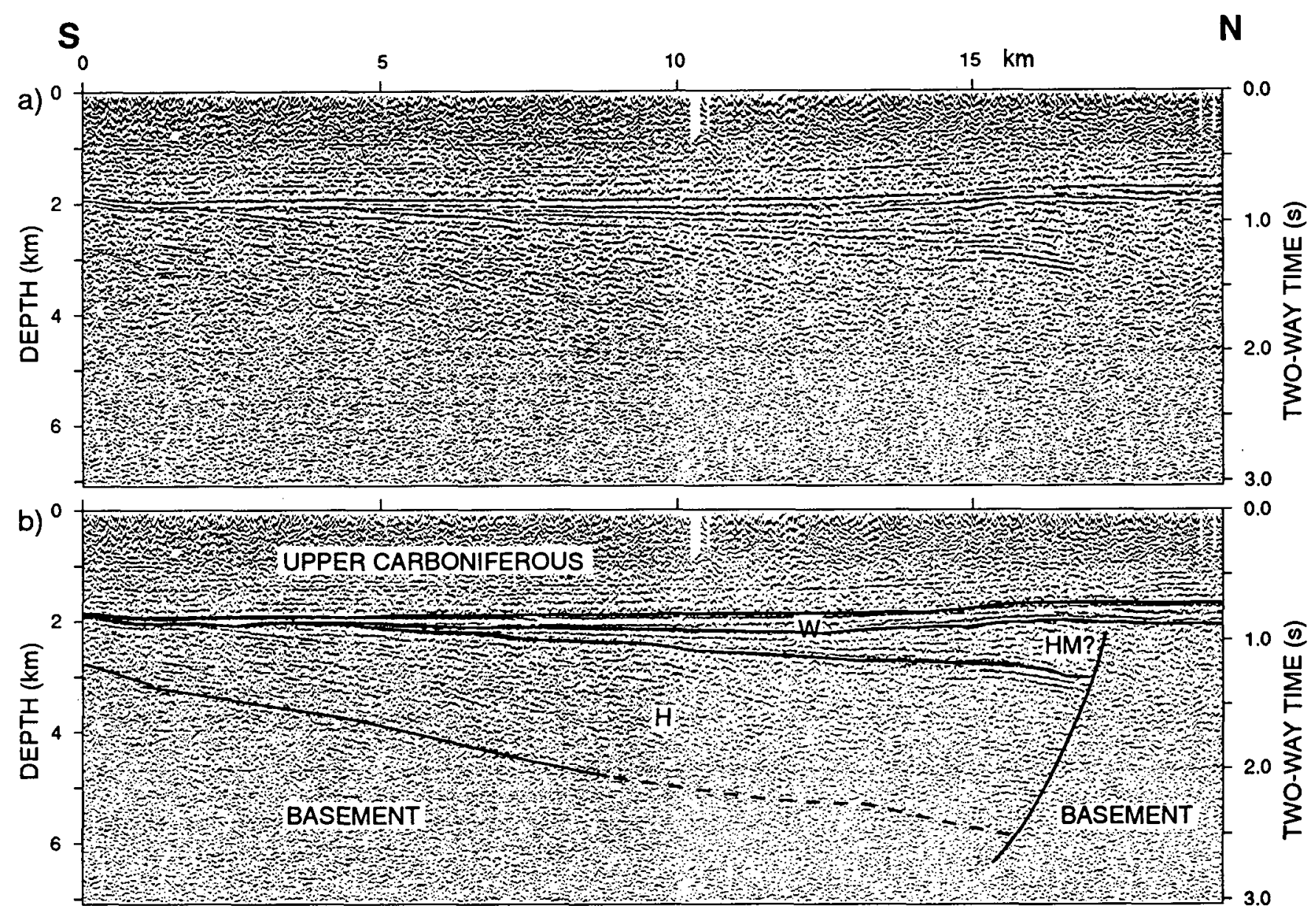

Fig. 10. Seismic section (1Y) across the northwestern tip of Prince Edward Island (a) uninterpreted and (b) interpreted. For location see Figures 3,6 , or 14 .

present on most of the offshore New Brunswick platform, in eastern Northumberland Strait and adjacent Prince Edward Island, and in the northeastern Magdalen Basin (Fig. 6). Accumulations of sediments greater than about $1000 \mathrm{~m}$, on the other hand, appear to represent the coalescence of several small subbasins forming broad areas of subsidence, or sag basins. For example, a large basin extends northwestward from the Magdalen Islands toward the Gaspe Peninsula; the fault bounded basin described earlier (Fig. 8) is located in the northwestern part of this sag basin. Another one covers most of eastern Prince Edward Island. The North Point Basin is a sag basin on the New Brunswick platform (Fig. 12). Onlap relationships occur along its eastern margin (which may represent a low angle fault), and to the west the strata are parallel to the basin floor.

\section{Deformation of the Horton Group basins}

Most of the Horton Group basins described above were deformed with varying degrees of intensity. The northwestern margin of the Malpeque Basin was deformed within a complex northeast striking fault zone. Beneath the Windsor Group and younger sediments we recognize three major structural units based on the varying style of deformation within this fault zone: the Egmont Bay High (van de Poll, 1983; St. Peter and Fyffe, 1990) and the McDougall and Wellington blocks (Figs. 13, 14). The Egmont Bay High, which is Acadian basement, represents the southeastern margin of the New Brunswick platform (Howie and Cumming, 1963; Durling and Marillier, 1990b) and the northwestern flank of the Malpeque Basin. Highly deformed Horton Group rocks, indicated by chaotic (Fig. 5d) to northwest dipping (Fig. 11) reflections, characterize the McDougall block. The Wellington block is the southernmost structural block in this complex fault zone. It is a zone of mildly deformed Horton Group rocks bounded to the south by one or more reverse faults. Between the McDougall and Wellington blocks, a narrow zone of chaotic reflections may represent basement rocks or highly deformed Horton Group (Fig. 11). This zone is at least $30 \mathrm{~km}$ long. Altogether, these blocks form a complex fault zone in which the intensity of deformation gradually diminishes towards the northeast. Where fault displacements are no longer recognized, the Malpeque Basin cannot be distinguished.

Faults in the Malpeque Basin record movements as young as post-Windsor Group and possibly as old as syn-Horton Group deposition. Post-Windsor Group faulting is supported by the seismic profiles crossing the Malpeque Basin which show that the youngest rocks affected are middle Windsor Group (Windsor subzone B; Giles and Durling, 1993) or younger rocks (Figs. 11,13 ), although we originally argued in favour of only a preWindsor Group event (Durling and Marillier, 1990a, b). A syn-Horton Group deformational episode is demonstrated in the Bradelle well area where upper Horton Group strata assigned to the Hillsborough Member (SOQUIP, 1987) unconformably 


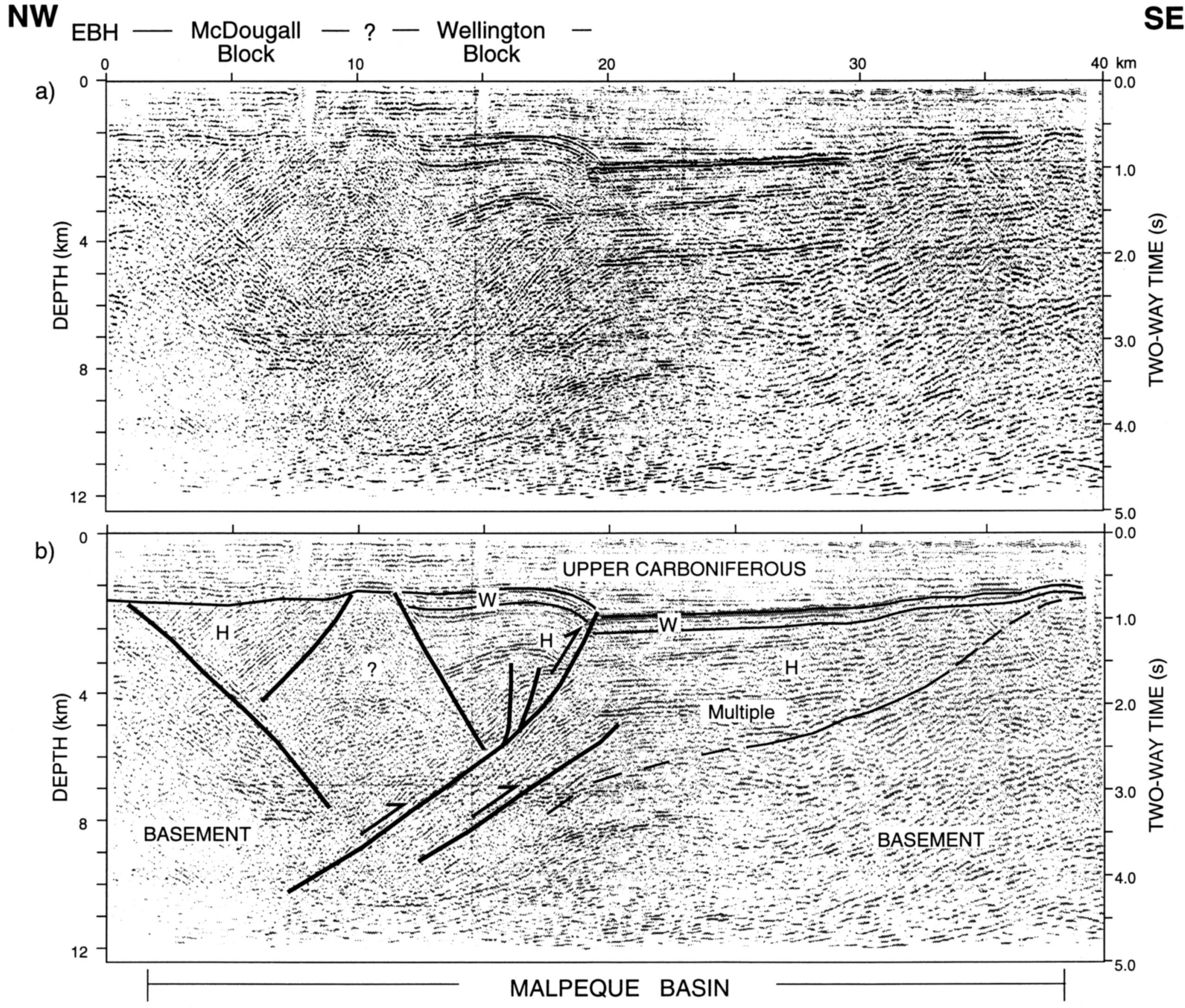

Fig. 11. Seismic section (GSL-98) across the southern part of the Malpeque Basin (a) uninterpreted and (b) interpreted. For location see Figures 3, 6, or 14. 


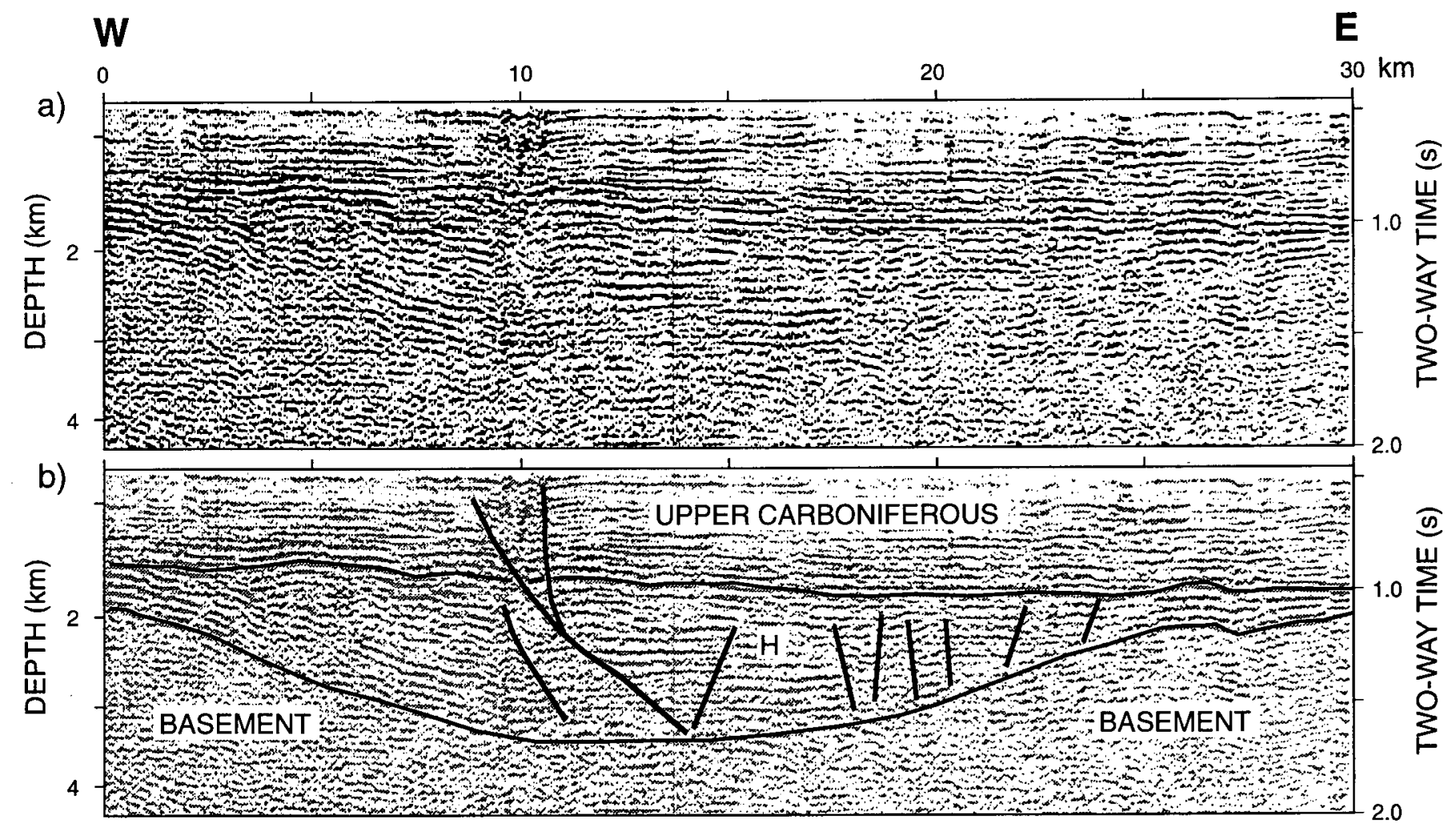

Fig. 12. Seismic section (HAC-009) across the North Point Basin, a "sag" basin (a) uninterpreted and (b) interpreted. For location see Figures 3 or 6 .

overlie older faulted and tilted Horton Group rocks (Fig. 8). In the Malpeque Basin, well logs indicate that flat lying Windsor Group clastic rocks (Howie and Cumming, 1963) overlie gently dipping $\left(35^{\circ}-55^{\circ}\right)$ Hillsborough Member strata, which in turn overlie vertically dipping Weldon Member rocks of the Horton Group (Howie and Cumming, 1963; Imperial Oil Limited, 1958). This suggests a pre-Windsor Group, and possibly a pre-Hillsborough Member, unconformity.

Deformation within the fault zone in the Malpeque Basin indicates two types of motion. Fault arrangements reminiscent of flower structures developed within the Wellington and McDougall blocks suggesting possible strike-slip motion; apparent reverse displacement on some faults suggests a thrust component. The contrasting pattern of seismic reflections in the McDougall and Wellington blocks may indicate that each of the tectonic episodes involved a different style and/or intensity of deformation. Webb (1963) believed, on the basis of fold orientations and fault displacements, that in the Moncton Basin there was a late Horton Group wrench-faulting episode followed by later reverse or thrust faulting. A similar interpretation may be made in the Malpeque Basin based on the available seismic and well data.

An intensely deformed, northeasterly striking basin is identified offshore from Cape Tormentine, New Brunswick (Fig. 15). It is up to $6 \mathrm{~km}$ deep, and it is bounded to the northwest by a basement block interpreted as the offshore extension of the Westmoreland uplift. A uniform thickness of Horton Group strata appears to extend beneath the highly deformed sediments suggesting thrusting. North dipping reflections beneath the base- ment block near $10 \mathrm{~km}$ depth may represent a fault plane along which south directed compressional motion occurred. The basin is on strike with the onshore Sackville Subbasin (Martel, 1987). Some offshore seismic profiles (e.g., Line 82-65-11L, Canada-Nova Scotia Offshore Petroleum Board, Project No. 8624-C4-14E) show a striking resemblance to figure 3 of Martel (1987) suggesting that the Dorchester Fault (Fig. 14) and the fault in Figure 15 at $10 \mathrm{~km}$ could be the same fault. These data, together with gravity and magnetic data, suggest that the Sackville Subbasin extends offshore into this highly deformed basin.

\section{Discussion}

Our isopach map of the Horton Group in the Magdalen Basin indicates that the distribution of these rocks differs significantly from previous interpretations (Howie and Barss, 1975). In particular, deep basins are recognized in a few localized areas, and sediment thickness does not systematically increase towards the Magdalen Islands. Previously derived subsidence models relying on the isopach map of Howie and Barss (1975) map should be reconsidered (e.g., Bradley, 1982).

\section{Basin formation}

Deep Horton Group subbasins are predominantly asymmetric fault bounded basins interpreted as half-grabens. The style of basin formation observed in the Magdalen Basin is compatible with relationships between the stratigraphy of sedimentary 


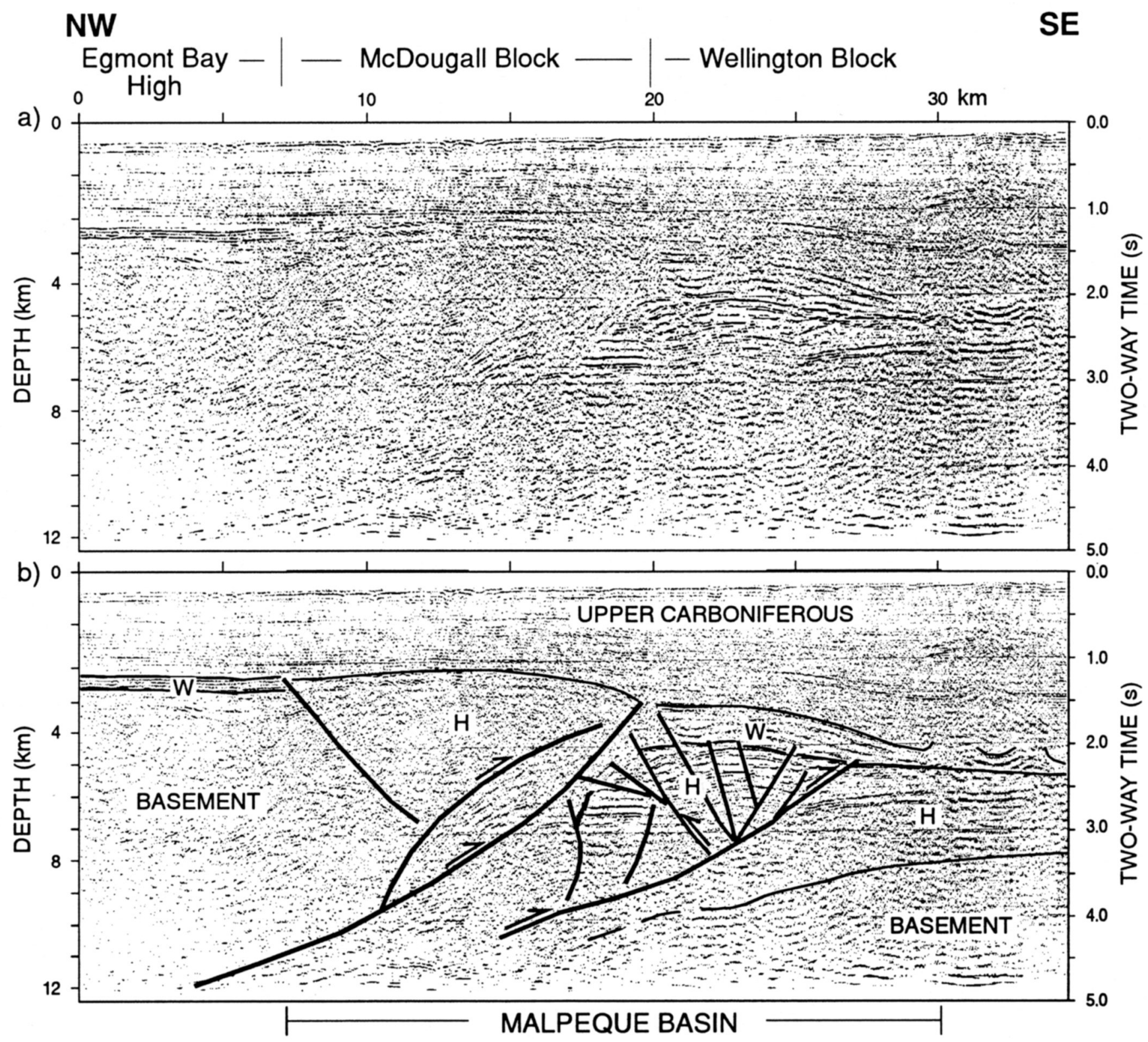

Fig. 13. Seismic section (GSL-90A) across the northern part of the Malpeque basin (a) uninterpreted and (b) interpreted. For location see Figures 3,6 , or 14 .

infill and syn-depositional dip-slip along master faults as documented for the Horton Group on Cape Breton Island (Hamblin and Rust, 1989).

Most of the half-grabens strike southwest-northeast (Fig. 6) and are dominantly located in the southern part of the Magdalen Basin. Together with the onshore basins of New Brunswick and Newfoundland, the Horton Group (or equivalent) basins form a wide zone extending from New Brunswick to Newfoundland across the Cabot Strait. The relationship between the Horton Group basins on Cape Breton Island and the offshore basins is not clear because they are separated by the Hollow Fault, a major Late Carboniferous strike-slip fault (Yeo and Ruixiang, 1987).

The basin in the Bradelle area is the only fault bounded basin striking northwest-southeast. While the fault bounded basins indicate that they formed during a phase of crustal exten- sion, their two trends are compatible with both a divergent wrench model and an orthogonal rift model (Durling and Marillier, 1993). Further discussion of these data is beyond the scope of this paper and will be presented elsewhere.

The widespread occurrence and the distribution of flat-lying Horton Group strata in sag basins or as thin veneers above Horton Group half-grabens, as well as a regional marine transgression and broad Windsor Group basins, suggest that a change in regional tectonics from crustal extension to regional subsidence occurred during the time of latest Horton Group deposition. Strata concordantly overlain by Windsor Group rocks were mapped regionally by SOQUIP (1987) in the sag basin located near the Bradelle well. These strata, interpreted by SOQUIP (1987) as the Hillsborough Member, may represent some of the first sediments deposited during this regional subsidence phase. Regional subsidence began at about the same time as the devel- 


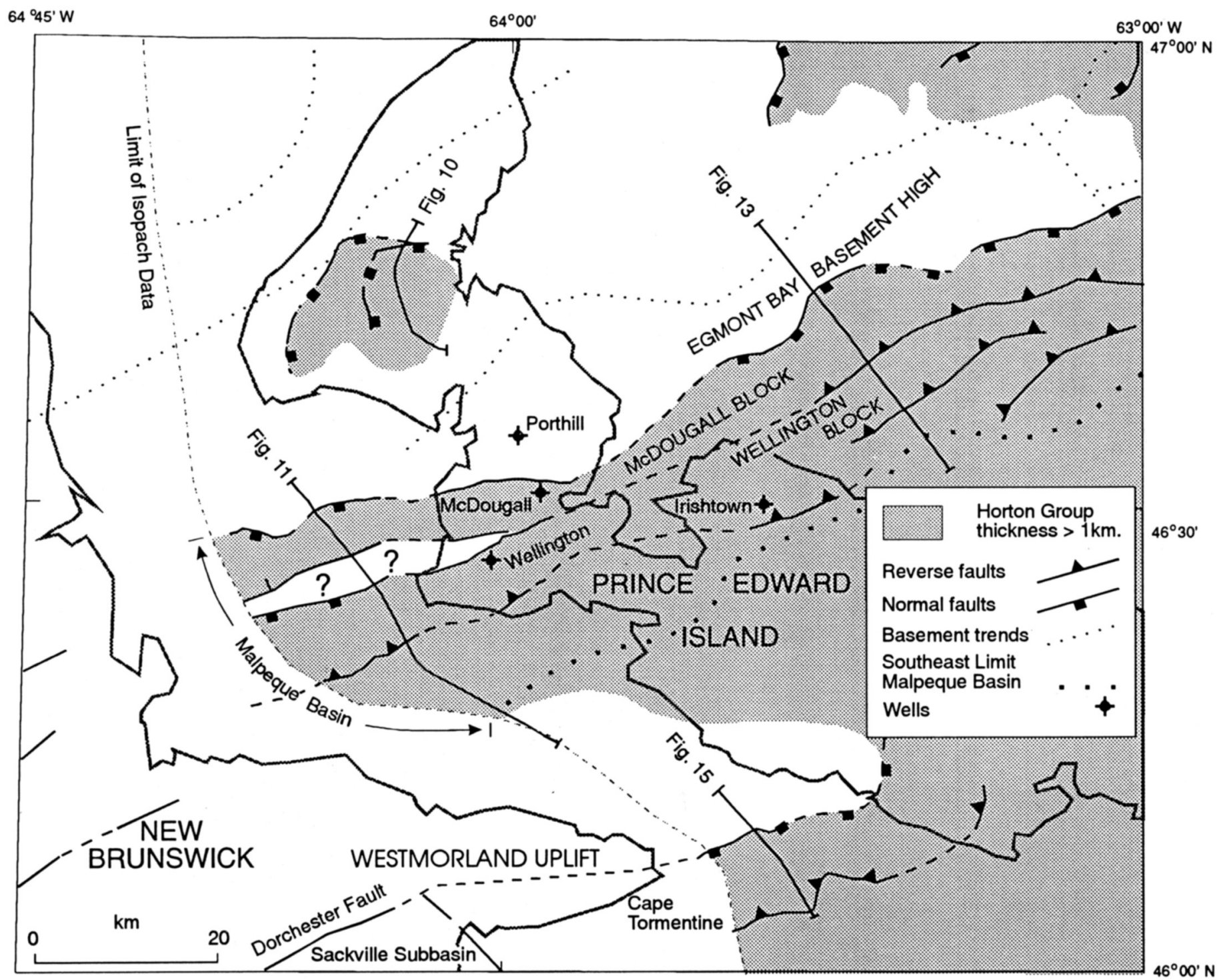

Fig. 14. Detailed map of the area between New Brunswick and Prince Edward Island. For location see Figure 1

opment of an intra-Horton Group unconformity (see next section).

\section{Deformation}

The most intense deformation is concentrated in northeast striking fault zones up to $20 \mathrm{~km}$ wide in the Malpeque Basin and offshore from Cape Tormentine. The fault zones and the basins do not extend across the Magdalen Basin; they abruptly end at least $50 \mathrm{~km}$ west of the area of Windsor Group salt flowage (Fig. 6). The east-west striking basin northeast of Prince Edward Island is only mildly affected by deformation. In other areas, shallower basins record minor faulting, folding and tilting of strata.

Deformation in the Malpeque Basin is characterized by folded and steeply dipping beds (as steep as vertical at the McDougall well), steep reverse faults affecting both sediments and basement, faults that separate mildly to highly deformed blocks (some of which are vertically displaced; Fig. 11), and fault arrangements that resemble positive flower structures (Fig.
13). Similar structures are observed in the Moncton Basin (Gussow, 1953; Webb, 1963).

Our data indicate two main phases of deformation, the first one near the end of Horton Group deposition, and the other during and shortly after deposition of the Windsor Group. The timing of the first phase is well constrained in the Bradelle area where Horton Group rocks beneath the Hillsborough Member are faulted and tilted whereas the Hillsborough strata are not. In the Malpeque Basin, well data from the McDougall well (Howie and Cumming, 1963) indicate that intense deformation is older than Windsor Group and younger than Weldon Member deposition. The age of deformation at both sites is compatible with the interpretation of a single pre-Hillsborough compressional event. Similar relationships occur onshore, where Horton Group clastic rocks rest unconformably on Upper Devonian clastic rocks (also Horton Group; Martel et al., 1993). Such relationships are observed in the Moncton Basin (Carter and Pickerill, 1985), the Antigonish Basin (Utting et al., 1989) and potentially in the St. Mary's (Murphy et al., 1993) and Shubenacadie (Utting et al., 1989) basins. This interpretation 

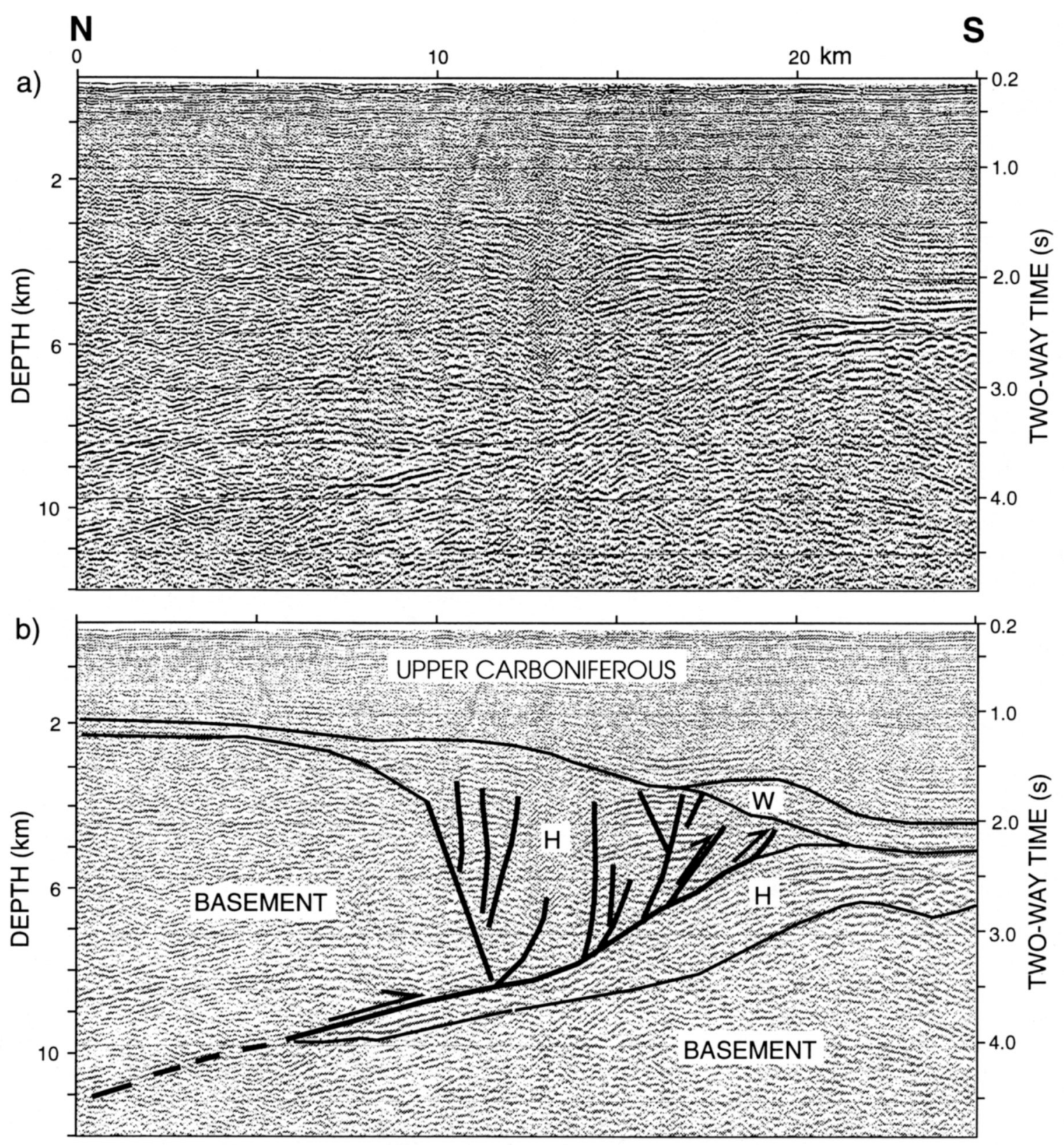

Fig. 15. Seismic section (QAK006) off Cape Tormentine in the Northumberland Strait (a) uninterpreted and (b) interpreted. For location see Figure 14

suggests that this event may have regional significance and raises the possibility of subdividing the Horton Group into two stratigraphic units in the Magdalen Basin. Although such a subdivision is recognized locally, we feel that regionally the seismic data quality is insufficient to permit systematic mapping of the unconformity.

The second phase of deformation is as old as syn-Windsor Group and as young as post-Windsor Group. The age of deformation is poorly constrained because Mabou rocks are absent in the fault zone, but faults and folds generally deform all Windsor Group rocks present. Undeformed rocks, possibly belonging to the Cumberland Group, provide an upper age limit.

A later phase of deformation is indicated in the vicinity of the Northumberland Strait F-25 well, where strata as young as Pictou Group are folded and faulted. This deformation may be related to Late Carboniferous movements along the Hollow and other faults between Cape Breton and Newfoundland (Knight, 1983; Yeo and Ruixiang, 1987).

\section{Conclusions}

Our isopach map of offshore Horton Group rocks in the Magdalen Basin indicates that this unit was deposited in two structural settings: (1) fault bounded basins, and (2) thin veneers and sag basins. The fault bounded basins, dominantly half-grabens, indicate a phase of crustal extension associated with brittle deformation. The flat lying thin veneers and sag basins are generally not associated with syn-depositional faults. They indicate a later phase of regional subsidence possibly due to thermal relaxation of the crust.

Two phases of compressional deformation are recognized. The older phase is associated with intense deformation of Horton 
Group rocks along northeast striking faults. It occurred prior to deposition of the Windsor Group. This deformational event is recognized regionally in the western Magdalen Basin and also locally onshore. During the second phase of deformation, the Windsor Group was faulted and gently folded. The age of this event is constrained in the Malpeque Basin by syn-depositional deformation in the Windsor Group and by undeformed ?Cumberland Group rocks.

\section{ACKnowledgements}

We gratefully acknowledge the contributions of the following individuals to this paper: J. Verhoef and $\mathrm{K}$. Usow for the use of their software to grid, contour and display our digital seismic data; Brian Nichols for his computer program to restore seismic reflection profiles on a flat horizon; P. Giles and C. St. Peter for stimulating discussions; and G. Grant, P. Parks and $\mathrm{F}$. Kelly for preparation of the figures. We also thank A. Grant, M.-C. Williamson, A. Hamblin and an anonymous referee for their constructive criticisms that substantially improved the manuscript.

This paper is Geological Survey of Canada Contribution No. 46593 .

Barss, M.S., Hacquebard, P.A., and Howie, R.D. 1963. Palynology and stratigraphy of some upper Pennsylvanian and Permian rocks of the Maritime Provinces. Geological Survey of Canada, Paper 63-3, 7 p.

Barss, M.S., Bujak, J.P., and Williams, G.L. 1979. Palynological zonation and correlation of sixty-seven wells, eastern Canada. Geological Survey of Canada, Paper 78-24, pp. 1-9.

Betr, E.S. 1968. Post-Acadian rifts and related facies, eastern Canada. In Studies of Appalachian Geology. Edited by E-an Zen, W.S White, J.B. Hadley, and J.B. Thompson, Jr. Wiley Interscience, New York, pp. 95-113.

Blanchard, M.-C., Jamieson, R.A., and More, E.B. 1984. Late Devonian-Early Carboniferous volcanism in western Cape Breton Island, Nova Scotia. Canadian Journal of Earth Sciences, 21, pp. 762-774.

Boehner, R.C., Calder, J.H., Carter, D.C., Donohoe, H.V., JR., Ferguson, L., Pickerill, R.K., and Ryan, R.J. 1986. Carboniferous-Jurassic sedimentation and tectonics: Minas, Cumberland and Moncton Basins, Nova Scotia and New Brunswick. Atlantic Geoscience Society, Special Publication Number 4, 122 p.

Bradley, D.C. 1982. Subsidence in late Paleozoic basins in the northern Appalachians. Tectonics, 1, pp. 107-123.

CARTER, D.C. and PICKERILL, R.K. 1985. Lithostratigraphy of the Late Devonian-Early Carboniferous Horton Group of the Moncton Subbasin, southern New Brunswick. Maritime Sediments and Atlantic Geology, 21, pp. 11-24.

Dostal, J., Keppie, J.D., and Dupuy, C. 1983. Petrology and geochemistry of Devono-Carboniferous volcanic rocks in Nova Scotia. Maritime Sediments and Atlantic Geology, 19, pp. 59-71

Durling, P. and Marillier, F. 1990a. Structural trends and basement rock subdivisions in the western Gulf of St. Lawrence, Northern Appalachians. Atlantic Geology, 26, pp. 79-95.

1990b. Structural trends and basement rock subdivisions in the western Gulf of St. Lawrence: Reply. Atlantic Geology, 26, pp. 281-284.
1993. Structural elements of the Magdalen Basin, Gulf of St Lawrence, from seismic reflection data. In Current Research, Part D, Geological Survey of Canada, Paper 93-1D, pp. 147-154.

GILES, P.S. 1981. Major transgressive-regressive cycles in the Middle to Late Visean rocks of Nova Scotia. Nova Scotia Department of Mines and Energy, Paper 81-2, 27 p.

Giles, P.S. and Durling, P.W. 1993. The Visean Windsor Group of the Magdalen Basin, eastern Canada, as imaged by seismic reflection data. Geological Association of Canada-Mineralogical Association of Canada, Joint Annual Meeting, Program and Abstracts, p. 35.

Grant, A.C and Molr, P.N. 1992. Observations on coalbed methane potential, Prince Edward Island. In Current Research, Part E, Geological Survey of Canada, Paper 92-1E, pp. 269-278.

Gussow, W.C. 1953. Carboniferous stratigraphy and structural geology of New Brunswick, Canada. Bulletin of the American Association of Petroleum Geologists, 37, pp. 1713-1816.

Hamblin, A.P. 1989. Sedimentology, Tectonic Control and Resource Potential of the Upper Devonian-Lower Carboniferous Horton Group, Cape Breton Island, Nova Scotia. Unpublished Ph.D. thesis, University of Ottawa, Ottawa, Ontario, 300 p.

Hamblin, A.P. and Rust, B.R. 1989. Tectono-sedimentary analysis of alternate-polarity half-graben basin-fill successions: Late Devonian-Early Carboniferous Horton Group, Cape Breton Island, Nova Scotia. Basin Research, 2, pp. 239-255.

Hobson, G.D. and Overton, A. 1973. Sedimentary refraction seismic surveys, Gulf of St. Lawrence. In Earth Science Symposium on Offshore Eastern Canada. Edited by P.J. Hood, N.J. McMillan, and B.R. Pelletier. Geological Survey of Canada, Paper 71-23, pp. 325-336.

HowIE, R.D. and Barss, M.S. 1975. Upper Paleozoic Rocks of the Atlantic provinces, Gulf of St. Lawrence and adjacent continental shelf. In Offshore Geology of Eastern Canada, Volume 2, Regional Geology. Edited by W.J.M. Van der Linden and J.A. Wade. Geological Survey of Canada, Paper 74-30, 2, pp. 35-50.

Howie, R.D and Cumming, L.M. 1963. Basement Features of the Canadian Appalachians. Geological Survey of Canada, Bulletin 89, $18 \mathrm{p}$.

IMPERIAL OIL LiMITED 1958. Wellington Station No. 1, Well History Log.

KELLY, D.G. 1967. Some aspects of Carboniferous stratigraphy and depositional history in the Atlantic Provinces. In Geology of the Atlantic Region. Edited by E.R.W. Neale and H. Williams. Geological Association of Canada, Special Paper No. 4, pp. 213-228.

KEPPIE, J.D. 1982. The Minas geofracture. In Major Structural Zones and Faults of the Northern Appalachians. Edited by P. St-Julien and J. Beland. Geological Association of Canada, Special Paper No. 24 , pp. 263-280.

KNIGHT, I. 1983. Geology of the Carboniferous Bay St. George subbasin, western Newfoundland. Mineral Development Division, Department of Mines and Energy, Government of Newfoundland and Labrador, Memoir 1, 358 p.

Marillier, F., Keen, C.E., Stockmal, G.S., Quinlan, G., Williams, H., Colman-SAdD, S.P., and O'Brien, S.J. 1989. Crustal structure and surface zonation of the Canadian Appalachians: implications of deep seismic data. Canadian Journal of Earth Sciences, 26, pp. 305-321.

Marillier, F.M. and Verheof, J. 1989. Crustal thickness under the Gulf of St. Lawrence, northern Appalachians, from gravity and deep seismic data. Canadian Journal of Earth Sciences, 26, pp. 1517-1532.

Martel, A.T. 1987. Seismic Stratigraphy and hydrocarbon potential of the strike-slip Sackville sub-basin, New Brunswick. In Sedi- 
mentary Basins and Basin-Forming Mechanisms. Edited by $\mathrm{C}$. Beaumont and A.J. Tankard. Canadian Society of Petroleum Geologists, Memoir 12, pp. 319-336.

Martel, A.T., McGregor, D.C., and Utting, J. 1993. Stratigraphic significance of Upper Devonian and Lower Carboniferous miospores from the type area of the Horton Group, Nova Scotia. Canadian Journal of Earth Sciences, 30, pp. 1091-1098.

McCutcheon, S.R. 1981. Stratigraphy and paleogeography of the Windsor Group in Southern New Brunswick. Unpublished M.Sc. thesis, Acadia University, Wolfville, Nova Scotia, 206 p.

Murphy, J.B., Meagher, C., and Mosher, S.J. 1993. Geological evolution of the eastern St. Mary's Basin: preliminary results. In Program and Summaries, Seventeenth Annual Review of Activities. Edited by D.R. MacDonald. Nova Scotia Department of Natural Resources, Mines and Energy Branches, Report 93-2, p. 53.

NANCE, R.D. 1987. Dextral transpression and Late Carboniferous sedimentation in the Fundy coastal zone of southern New Brunswick. In Sedimentary Basins and Basin-Forming Mechanisms. Edited by C. Beaumont and A.J. Tankard. Canadian Society of Petroleum Geologists, Memoir 12, pp. 363-377.

Nickerson, W.A. 1991. Seismic clues to Carboniferous basin development in the Moncton Subbasin, New Brunswick. Atlantic Geology, 27, p. 159

Pe-PIPER, G. and JANSA, L. 1986. Triassic olivine-normative diabase from Northumberland Strait, eastern Canada: implications for continental rifting. Canadian Journal of Earth Sciences, 23, pp. 1013-1021.

Poole, W.H. 1967. Tectonic evolution of the Appalachian Region of Canada. In Geology of the Atlantic Region. Edited by E.R.W. Neale and H. Williams. Geological Association of Canada, Special Paper No. 4, pp. 9-51.

Ruitenberg, A.A and McCutcheon, S.R. 1982. Acadian and Hercynian structural evolution of southern New Brunswick. In Major Structural Zones and Faults of the Northern Appalachians. Edited by P. St-Julien and J. Beland. Geological Association of Canada Special Paper No. 24, pp. 131-148

Ryan, R.J., BOeHneR, R.C., and CALDER, J.H. 1991. Lithostratigraphic revisions of the Upper Carboniferous to Lower Permian strata in the Cumberland Basin, Nova Scotia and the regional implications of the Maritimes Basin in Atlantic Canada. Bulletin of Canadian Petroleum Geology, 4, pp. 289-314.
Shell-Soquip-Amoco Bradelle L-49. 1974. Well history report. Canada Oil and Gas Lands Administration, Department of Energy Mines and Resources, Canada.

St. Peter, C. 1992. Lithologic facies, seismic facies, and strike-slip setting of the Lower Carboniferous alluvial/fluvial/lacustrine Albert Formation of New Brunswick. New Brunswick Department of Natural Resources and Energy, Geoscience Report 92-2, $145 \mathrm{p}$.

St. Peter, C.J. and FyfFe, L.R., 1990. Structural trends and basement sub-divisions in the western Gulf of St. Lawrence: Discussion. Atlantic Geology, 26, pp. 277-279.

Soquip 1987. Estuary and Gulf of St. Lawrence: geological-geophysical-geochemical data integration. Geological Survey of Canada, Open File Report 1721, 73 p.

Utting, J., KePPIE, J.D., and Giles, P.S. 1989. Palynology and stratigraphy of the Lower Carboniferous Horton Group, Nova Scotia. In Contributions to Canadian Paleontology, Geological Survey of Canada, Bulletin 396, pp. 117-143.

van DE Poll, H.W. 1983. Geology of Prince Edward Island. Department of Energy and Forestry, Energy and Minerals Branch, Province of Prince Edward Island, Report 83-1, 66 p.

WeBb, G.W. 1963. Occurrence and exploration significance of strike-slip faults in southern New Brunswick, Canada. Bulletin of the American Association of Petroleum Geologists, 47, pp. 1904-1927.

1969. Paleozoic wrench faults in the Canadian Appalachians. In North Atlantic Geology and Continental Drift. Edited by M. Kay. American Association of Petroleum Geologists, Memoir 12, pp. $754-786$

Williams, G.L., FyfFe, L.R., Wardle, R.J., Colman-SadD, S.P., and BOEHNER, R.C. 1985. Lexicon of Canadian Stratigraphy, Volume VI, Atlantic Region. Canadian Society of Petroleum Geologists, Calgary, 572 p.

Yeo, G.M. and Ruixiang, G. 1987. Stellarton Graben: an Upper Carboniferous pull-apart basin in northern Nova Scotia. In Sedimentary Basins and Basin-Forming Mechanisms. Edited by C. Beaumont and A.J. Tankard. Canadian Society of Petroleum Geologists, Memoir 12, pp. 299-309. 